OPEN ACCESS

Edited by:

Aurelio Cafaro,

Istituto Superiore di Sanità (ISS), Italy

Reviewed by:

Christiane Moog

Institut National de la Santé et de la

Recherche Médicale (INSERM).

France

Cristian Apetrei,

University of Pittsburgh, United States

*Correspondence:

Liuzhe Li

liuzhe.li@nyumc.org

Specialty section

This article was submitted to

Viral Immunology,

a section of the journal

Frontiers in Immunology

Received: 20 July 2018 Accepted: 06 November 2018 Published: 26 November 2018

Citation:

Li L, Liu Y and Gorny MK (2018) Association of Diverse Genotypes and

Phenotypes of Immune Cells and

Immunoglobulins With the Course of

HIV-1 Infection.

Front. Immunol. 9:2735

doi: 10.3389/fimmu.2018.02735

\section{Association of Diverse Genotypes and Phenotypes of Immune Cells and Immunoglobulins With the Course of HIV-1 Infection}

\author{
Liuzhe Li ${ }^{1 *}$, Yan Liu ${ }^{2}$ and Miroslaw K. Gorny ${ }^{1}$ \\ ${ }^{1}$ Department of Pathology, New York University School of Medicine, New York, NY, United States, ${ }^{2}$ Institute of Pathogenic \\ Biology, Medical College, University of South China, Hengyang, China
}

Disease progression among HIV-1-infected individuals varies widely, but the mechanisms underlying this variability remains unknown. Distinct disease outcomes are the consequences of many factors working in concert, including innate and adaptive immune responses, cell-mediated and humoral immunity, and both genetic and phenotypic factors. Current data suggest that these multifaceted aspects in infected individuals should be considered as a whole, rather than as separate unique elements, and that analyses must be performed in greater detail in order to meet the requirements of personalized medicine and guide optimal vaccine design. However, the wide adoption of antiretroviral therapy (ART) influences the implementation of systematic analyses of the HIV-1-infected population. Consequently, fewer data will be available for acquisition in the future, preventing the comprehensive investigations required to elucidate the underpinnings of variability in disease outcome. This review seeks to recapitulate the distinct genotypic and phenotypic features of the immune system, focusing in particular on comparing the surface proteins of immune cells among individuals with different HIV infection outcomes.

Keywords: HIV-1, HIV-1 disease progression, immune cells, surface proteins, immunoglobulin, genotype, phenotype

\section{INTRODUCTION}

People infected with HIV-1 exhibit remarkable variation in disease progression. The outcome of HIV-1 infection is categorized into three groups: (a) long-term non-progressors (LTNPs), who can be subdivided into elite controllers (those with $\mathrm{CD} 4^{+} \mathrm{T}$ cell counts $>500 / \mathrm{mm}^{3}$, undetectable viral load [VL], and spontaneous control of HIV-1 without antiretroviral therapy [ART] for more than 7 years and virus controllers (those who establish and retain effective control of HIV- 1 for $<7$ years); (b) typical progressors (TPs); and (c) rapid progressors (RPs). About 5-15\% of all HIV-1-infected individuals are LTNPs, and fewer than $1 \%$ of all HIV-1-infected individuals are elite $(1,2)$. In TPs and RPs who do not receive treatment, CD4 ${ }^{+}$T-cell counts fall below $200 / \mathrm{mm}^{3}$, and VLs rise above 10,000 copies/mL. In the absence of intervention, TPs progress to AIDS within 3-7 years, and RPs in $<3$ years ( 3 ). 
The outcome of HIV-1 infection depends on both viral and host factors; the latter include features of cellular (CD4 and CD8 cells), humoral (B cells), and innate immunity (NK cells). Based on multiple analyses, it is clear that both genotypes (e.g., HLA) and phenotypes (e.g., CD73) contribute to the eventual outcome of HIV-1 infection in both LTNPs and progressors. Studies of HIV-1-infected individual pairs in which the same replication-competent viruses from elite controllers resulted in progressive disease in other patients have also provided solid evidence for the roles of the host genetic and phenotypic factors $(4,5)$. Modern clinical medicine is moving in the direction of personalized medicine based on the individual patient's response to treatment. The ontogeny based strategies for HIV vaccine design was recently emphasized by researchers (6).

In this review, we focus on comparing the genotypes and phenotypes of immune cell-surface proteins and immunoglobulins (Igs), which constitute the first line of interaction between host and virus, among individuals with different HIV infection outcomes.

\section{RESULTS}

\section{HLA Genes Associated With Favorable and Unfavorable Outcomes of HIV Infection}

Human leukocyte antigen (HLA) alleles play vital roles in the cellular immune response to HIV infection. Several HLA alleles protect against or promote susceptibility to HIV-1 infection $(7,8)$. The protective or sensitizing effects of HLA genes are mediated by cytotoxic T lymphocytes (CTLs) capable of recognizing a broad spectrum of epitopes: the protective alleles enable these cells to kill HIV-infected target cells (7), whereas sensitivity can result from inhibitory effects on NK cells (9).

HLA-B ${ }^{*} 57$, the most widely recognized protective allele (1014 ), is strongly associated with slow HIV-1 disease progression in multiple ethnicities, including Caucasians (15) and African Americans (16). In a cohort study, 29 of 66 (44\%) elite and 20 of $60(33 \%)$ virus controllers carried HLA-B*57, whereas only $10 \%$ of chronic progressors carried this allele (17). The protective HLA-B* 57 allele is associated with the induction of a restricted CTL response (18). In mechanistic terms, the protective effects of the HLA-B*57 allele relate to the breadth, magnitude, immunodominance, and affinity of the T-cell response. The peptide-binding groove of the MHC molecule facilitats the negative thymic selection of $\mathrm{T}$ cell clones due to fewer selfpeptides able to bind to HLA-B* 57 molecules, it leads to higher precursor frequency for viral epitopes, which would result in more cross-recognition of viral epitope variants and greater response magnitude to viral epitopes (19). HLA-B*57 molecules have an intrinsic preference for presenting epitopes from p24, one of the most conserved regions of the HIV genome, further contributing to improved cross-recognition (20). HLA-B*57restricted CTL responses exhibit exceptionally high affinity and dominate the HLA-A*02-restricted CTL response in individuals co-expressing both alleles (21). Furthermore, HLA$B^{*} 57$ molecules engage in cross-talk with innate immune cells by acting as ligands for the KIR3DL1 family of killer immunoglobulin-like receptors (KIR) on natural killer (NK) cells; these NK cells exhibit greatest multi-functionality among NK cells from subjects with different HLA-B alleles (22).

Another HLA genotype associated with control of HIV infection is HLA-B*27 (23, 24), which is significantly overrepresented among individuals that progress slowly to AIDS. As with HLA-B*57, HLA-B*27-restricted CTLs play a crucial role in controlling HIV-1 by presenting HIV-1 conserved epitopes of Gag p24 (25). However, in contrast to HLA-B*57, HLA-B*27-restricted CTL responses do not have particularly high affinity and do not dominate the response in individuals co-expressing HLA-A*02. On the contrary, HLA-B*27 enhances the responsiveness of $\mathrm{HIV}$-specific $\mathrm{T}$ cells restricted through HLA-A*02, implying a distinct mechanism (21).

For ethnicities in which HLA-B*57 and HLA-B*27 are uncommon, other HLA-B alleles play protective roles. For example, HLA-B*6701 and HLA-B*5201-C*1202 haplotypes are protective alleles found in Japanese individuals with HIV infection, CTLs restricted by these alleles control HIV-1 infection progress $(26,27)$. Similarly, HLA-B*5801 and HLA-B*3505 mediate protective effects in Africans (28) and Thai patients infected with subtype CRF01_AE (29).

Both HLA-C alleles (30-32) and the level of HLA-C expression are associated with HIV control $(12,33,34)$. HLA-C*1403 and HLA-C 1202 confer protective effects in chronically infected Japanese (32) and subtype AE-infected Vietnamese patients (31). A single-nucleotide polymorphism (SNP) in the HLA-C gene affects post-infection outcome by influencing surface expression of HLA-C protein (35). Induction of HLA-C expression by SNP rs9264942 - 35 C is associated with lower HIV-1 VLs in ARTnaive individuals, whereas $-35 \mathrm{~T}$ allele, which decreases surface expression of HLA-C, is associated with relatively rapid disease progression $(13,34,36)$. The protective effects of HLA-C can be mediated either by ligand-receptor interactions with KIRs (32), by induction of superior cytotoxic $\mathrm{T}$ cell activity via antigen presentation to cytotoxic $\mathrm{T}$ cells $(37,38)$, or likely by linkage disequilibrium with protective HLA-B alleles $(39,40)$.

Other HLA class I alleles associated with resistance to HIV or slower progression to AIDS include HLA-A*02 (41), HLA$A^{*} 11(42)$, HLA-A*7401 (43), HLA-B*18 (44), HLA-B*40 (44), HLA-B*81 (45), HLA-B*1402 (46), HLA-B*5101(47), and HLAC8 (24). HLA-A*02 decreases the risk of HIV transmission to infants during childbirth by 9 -fold, possibly by stimulating peripheral blood mononuclear cells that inhibit HIV replication (48). Notably, in the RV144 HIV-1 vaccine trial, carriers of HLA $\mathrm{A}^{*} 02$ exhibited better vaccine efficacy than non-carriers $(74 \%$ vs. $15 \%, P=0.02$ ) against viruses harboring $\mathrm{K} 169$; this site is essential to antibody binding, implying that immune pressure contributed to this effect (49). HLA-B*18 is also associated with protection against mother-to-child HIV-1 transmission: infants with HLA B* 18 are $74 \%$ less likely to be infected at the age of 1 month, and no uninfected breastfeeding infants expressing HLA $\mathrm{B}^{*} 18$ at 1 month subsequently acquire HIV-1 via the breast milk (50).

Unexpectedly, HLA-A*02 haplotypes such as HLA-A*02$\mathrm{Cw}^{*} 16$ and HLA-A*02-B*45- $\mathrm{Cw}^{*} 16$ appear to contribute to 
higher VLs in HIV-infected Zambians (51). HIV has evolved to evade immune recognition by several mechanisms. For example, the viral accessory protein Nef binds to the cytoplasmic tail of class I HLA-A and B molecules, causing them to migrate to the lysosomes for degradation; this prevents surface expression of HLA molecules and thereby impairs CTL recognition of virusinfected cells $(52,53)$. In addition, HLA-B*35Px (54), HLA-B*08 (8), and HLA-A*24 alleles (55) are associated with relatively rapid progression to AIDS. Infants carrying HLA-A*29 are at 2-fold greater risk of acquiring HIV acquisition: in one study, 13 (25\%) of 52 infants expressing HLA A*29 became infected by month 1 , in comparison with 52 of 381 (13.7\%) without this allele (50). Moreover, class I HLA-B*7 is correlated with accelerated disease progression in B-clade infection, but not in C-clade infection (56).

Allele-specific interactions between HLA class I molecules and their receptors on dendritic cells can significantly influence HIV1 disease outcomes (57). Carriers of HLA-B*35 exhibit marked differences in resistance or vulnerability to HIV infection. Carriers of certain subtypes of HLA-B*35 progress more rapidly to HIV disease due to an interaction between HLA class I and inhibitory leukocyte immunoglobulin-like receptors (LILRs) expressed on dendritic cells, which leads to impaired dendritic cell function (57). HLA-B*35 alleles can be classified into $B^{*} 35$ Px and $B^{*} 35-P y$ subtypes. HLA-B*35-Px molecules bind peptides with a proline $(\mathrm{P})$ at anchor residue 2 , and accommodate a range of residues at position 9, whereas HLA-B*35-Py molecules bind peptides with a proline at residue 2 but only when tyrosine (Y) is present at position 9 (58). In contrast to non-HLA$B^{*} 35-P x$ subtypes, HLA-B*35-Px subtypes (B*3502, B*3503, $B^{*} 3504$, and $\left.B^{*} 5301\right)$ are associated with faster HIV-1 disease progression $(P<0.0001)$ and have significantly higher mean HIV RNA set points $(p=0.04)$ in infected individuals in the United States and Europe (54). The putative HLA-B*35-Py allele $B^{*} 3505$ is protective in Thais infected with subtype CRF01_AE, a population in which the frequency of HLA-B*57 is low (29). However, the protective effect is not consistent across ethnicities: in a Peruvian MSM cohort, it was associated with increased VL (59).

Immune responses to HLA-B*35-Px- or HLA-B*35-Pyrestricted HIV-1-specific CTL epitopes exhibit different patterns. Measurements of the immune response to variant peptides reveal that HLA-B*35-Py carriers do not recognize variant epitopes alone. Conversely, all HLA-B*35-Px carriers, who are expected to have limited recognition of epitope variants, are able to respond to all variants (60). Thus, the protective effect of HLA-B*35-Py may be compensated by other mechanisms.

During chronic HIV-1 infection, immunoglobulin-like transcript 4 (ILT4), a prominent inhibitory myelomonocytic MHC class I receptor expressed primarily on monocytes and dendritic cells, is significantly up-regulated (57). Ex vivo assessments revealed that HLA-B*3503 binds to ILT4 more strongly than HLA-B*3501, independent of the epitopes presented, leading to greater functional impairment of dendritic cells. However, HLA-B*3501-mediated protection from HIV-1 infection is not uniquely due to lower-affinity binding to ILT4, and may also be a result of the altered breadth of the $\mathrm{CD} 8^{+}$
T cell response. Subjects with HLA-B*3501 more effectively controlled $\mathrm{C}$ clade infection than $\mathrm{B}$ clade infection, because of polymorphism in gag epitopes which were weakly recognized by CD8 cells (61). Nevertheless, in another large HIV-1-infected cohort in Mexico (62), HLA-B*3501 had a significant negative influence on plasma VL.

The deleterious effect of elevated expression of HLA-A on virus and $\mathrm{CD}_{4}{ }^{+} \mathrm{T}$-cell has been observed in $9763 \mathrm{HIV}$-infected individuals from 21 cohorts. The negative impact is mediated by elevated expression of HLA-E, which serves as a ligand for the inhibitory NK cell receptor NKG2A; the resultant increase in NKG2A-mediated NK (and/or T-cell) inhibition impairs elimination of HIV-infected target cells (9). Homozygous carriers of HLA-A,-B, and -C confer a significant risk of accelerated infection due to the smaller range of class I molecules available for antigen presentation to CTLs in comparison to heterozygous carriers (63). In general, HLA-B may be more protective against HIV-1 than HLA-A because it confers greater resistance to Nefmediated down-regulation of HLA-I surface expression (64).

For HLA-class II, several DQB1 alleles and DQ haplotypes are associated with resistance or susceptibility to HIV-1 infection. In an association study of a cohort of 978 sex workers in Kenya, resistance-relevant alleles included DQB1*0603, DQB1*0609, DQB1*050301, and the DQA1*010201-DQB1*0603 haplotype; these associations were inferred from HIV-1-resistant women who remained HIV seronegative for at least 3 years while continuing active sex work (65). On the whole, DQB1*0602 and the DQA1*010201-DQB1*0602 haplotype were significantly overrepresented in the HIV-1-infected population. Moreover, haplotypes DQA $1^{*} 0504-\mathrm{DQB} 1^{*} 0201$, DQA $1 * 010201-D Q B 1 * 0201$, DQA $1 * 0402-D Q B 1 * 0402$, and DQA $1^{*} 0402-\mathrm{DQB} 1 * 030101$ were only found in HIV-1-positive women who seroconverted rapidly (65). Another analysis comparing HLA-DQ marker frequencies between the regional control population (98 African Americans, 143 Caucasians) and the disease population (30 African Americans and 22 Caucasians) linked HLA-DQB1*0603 ( $p=0.04$ ) with protection in Caucasians. By contrast, a significantly increased risk of HIV infection is associated with HLA-DQB1*0602 $(p=0.04)$ in Caucasians, and with HLA-DQB1*0605 $(p=0.05)$ in African Americans (66). In a Spanish cohort of HIV-exposed seronegative (HESN) individuals, DQB1*0302 was associated with immune protection against HIV infection (67). In addition, Class II HLA-DR2 is associated with susceptibility to HIV infection (42) and pulmonary tuberculosis (PTB) in Indians (68).

The association between HLA and HIV infection outcome has been extended to analyses of HIV-1 superinfection. Elevated HIV-1 superinfection risk has been observed in carriers of HLA$\mathrm{B}^{*} 35(p=0.017 ; P=0.020), \mathrm{HLA}-\mathrm{C}^{*} 04(p=0.010 ; P=0.033)$, and HLA-DRB1 ${ }^{*} 08(p=0.011 ; P=0.027)$ using univariate and multivariate analyses (69).

In summary, various HLA alleles have been associated with either protective or deleterious impacts on HIV infection outcome (Table 1). The mechanisms underlying these effects include restricted CTL responses via the intrinsic breadth and affinity of HLA molecules for viral epitopes, cross-talk with NK cells as ligands to activate or inhibit innate immune cells, and 
TABLE 1 | HLA alleles and chemokine receptor genotypes relevant to the outcome of HIV-1 infection.

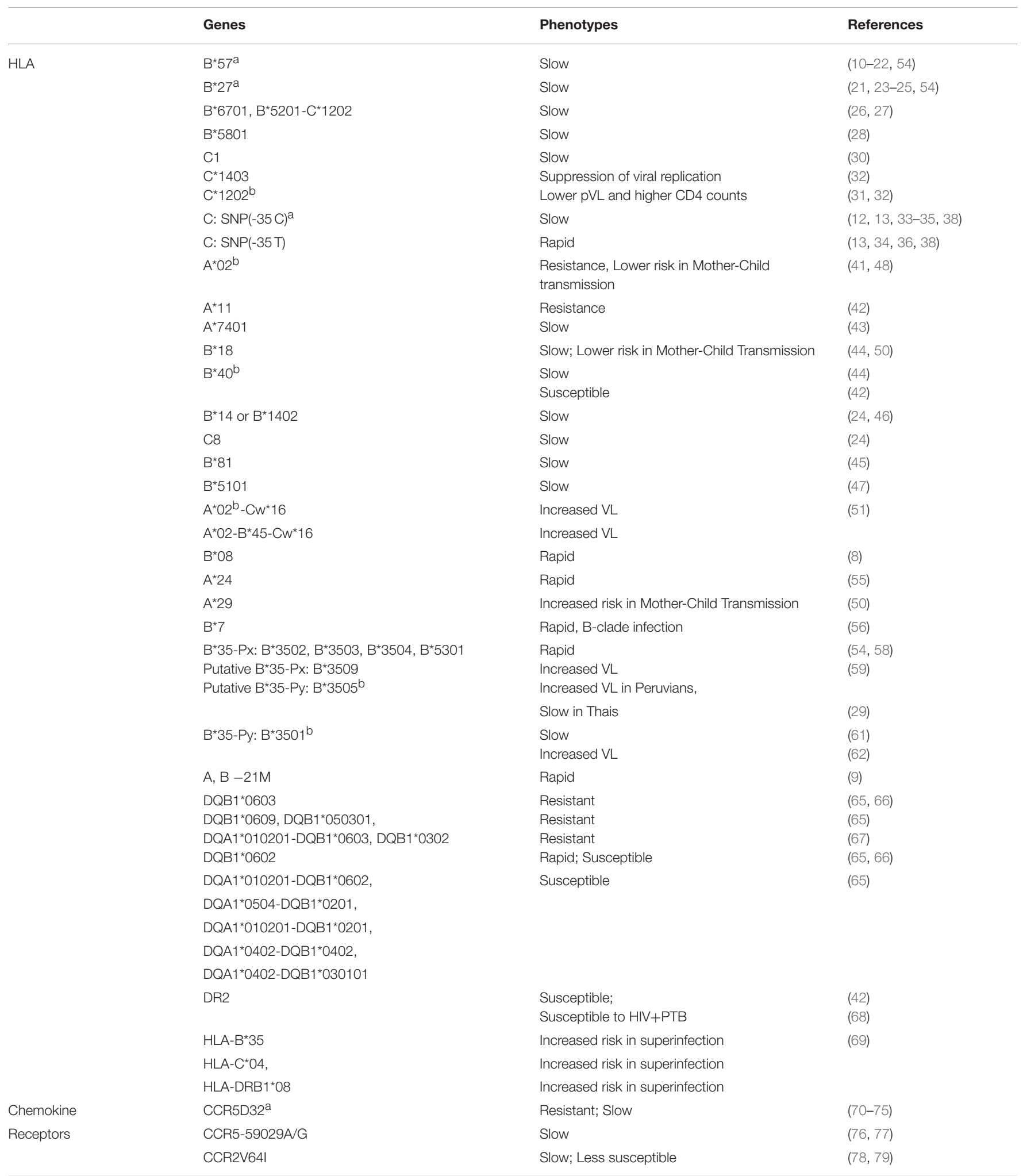

a Protective effect deduced from multiple independent studies.

${ }^{b}$ Controversial roles in disease progress. 
the influence of cell-surface expression of HLA molecules on antigen presentation. The beneficial and deleterious effect of each HLA allele has not yet been comprehensively elucidated, in part due to the properties of the HIV-specific CTL reaction and the complexity of HLA allele profiles in individuals. In addition, in contrast to the solely protective effects of HLA-B*57 and $\mathrm{B}^{*} 27$ reported in multiple studies, other alleles, such as HLA$\mathrm{A}^{*} 02$ and HLA-B*35 Px/Py subtypes, have opposing effects on disease progression, as demonstrated in studies in which HLA alleles have to be evaluated in specific genetic background in order to detect synergies or counteracting effects. HLA alleles can either act independently or function together. Accordingly, the influence of HLA alleles on disease outcome must be determined via various types of genetic dissection.

\section{Chemokine Receptors Involved in the Impairment of HIV-1 Infection}

HIV-1 virus invades host CD ${ }^{+}{ }^{+} \mathrm{T}$ cells via interactions between CD4 and chemokine receptors on the target cells and the corresponding CD4 and co-receptor binding sites on the viral envelope. Variations in the genes encoding chemokine receptors and their natural ligands influence the rate of HIV1 disease progression (Table 1). Both innate (monocytes and macrophages) and adaptive immune cells ( $\mathrm{T}$ cells) express chemokines receptors, and play crucial roles in HIV-1 virus entry and progression.

Chemokines are classified into four subfamilies: C, CC, CXC, and CX3C (80). HIV T-tropic or X4 strains preferentially infect T cells, whereas M-tropic or R5 strains infecting both macrophages and T cells. CCR5 (R5-tropic) and CXCR4 (X4-tropic) are the two main chemokine receptors involved in HIV infection. CCR5 is the major co-receptor for binding of HIV-1 envelope, and thus mediates membrane fusion and signal transduction. CCR5 and CCR2 have been implicated in the HIV-1 transmission and progression of HIV infection. A 32-bp deletion mutation in the CCR5 open reading frame (ORF) (CCR5 432$)$ found in Caucasians leads to a frameshift, resulting in abrogated expression of the receptor on the cell surface. Strikingly, homozygosity for CCR $5 \Delta 32$ confers nearly complete protection against HIV infection (70). A survival analysis revealed that disease progression is slower in CCR $5 \Delta 32$ heterozygotes than in CCR5-wild-type (WT) homozygotes (71), and this observation was reproduced in other studies. For instance, one study showed that reduced cell surface CCR5 in CCR5 WT/ $\Delta 32$ heterozygotes yielded limited protection, whereas $\Delta 32$ homozygotes were almost completely resistant to HIV infection (72). Meta-analysis of 5,963 HIV-infected individuals and 5,048 controls confirmed that among Caucasians, the risk of HIV infection is at least $13 \%$ lower in CCR5 WT/ $\mathbf{W} 32$ heterozygotes than in CCR5 WT/WT homozygotes (73). Additional evidence for the protective role of the CCR $5 \Delta 32$ allele is provided by the population of Vlach Gypsies in Hungary, in which the frequency of CCR5 $\Delta 32$ is elevated and the incidence of HIV/AIDS is lower (74). The most famous case of CCR $5 \Delta 32$ is the "Berlin patient" who was the first and only patient cured of HIV by receiving stem cells homozygous for CCR5 $\Delta 32$ during treatment of acute myeloid leukemia (AML) (75). The Berlin patient has been free of ART with undetectable HIV since 2008, when he underwent transplantation.

As with HLA, SNPs of CCR5 impact HIV disease progression. Genetic polymorphism CCR5-59029A/G, an A-to-G substitution at position 2459 upstream of the CCR5 translation start site in the gene's promoter region, slowed progression to AIDS by an average of 3.8 years $(p=0.004)$. The protective effect may be the result of reduced CCR5 mRNA production: in vitro promoter activity measurements revealed that $59029 \mathrm{G}$ was $45 \%$ less active than 59029A (76). However, the association of CCR559029A/G with host resistance to HIV-1 infection was not detected in Chinese Han and Indian population $(81,82)$. The CCR5-59356C/T polymorphism had a mixed effect on disease progression in terms of CD4 ${ }^{+}$counts and VL $(77,82)$, possibly due to the genetic profiles of the ethnicities involved. In vitro functional assays of several SNP of CCR5, including C20S, C178R, A29S, L55Q, C101X, and FS299 (83) resulted in aberrant expression on the cell surface, alteration of ligand binding affinity, or inability to mediate receptor activation, all of which could influence disease progression in vivo.

Expression of CCR2, which mediates attraction of monocytes to inflamed tissue (84) is relatively restricted to certain types of cells, mainly circulating monocytes. In addition, CCR2 serves as a minor HIV co-receptor, although the tropism has not been precisely defined. CCR2V64I or 46295G/A, a mutation in the first transmembrane region, is common in all ethnic groups. A genetic association analysis of 1746 AIDS patients revealed a $30-80 \%$ increase in the CCR2V64I allele frequency in virus controllers. In a combination of five AIDS cohorts constituting a total of 3003 patients, CCR2V64I was associated with 2-4 years postponement of AIDS relative to homozygotes for the other allele; however, disease delay was not linked to CCR2 genotype in the ALIVE cohort, which consisted of 94\% African Americans (78). Nonetheless, the association of CCR2V64I with lower susceptibility to HIV-1 infection has been observed in a cohort of African Americans (79). In vitro experiments suggested that the protective effect of CCR2 V64I is likely mediated by binding to CCR5 in the cytoplasm, preventing it from being expressed on the cell surface (85). Genetic variation in CXCR2, a receptor for IL-8, has not been significantly associated with HIV-1 VL or CD4 count, although the CXCR2 $(+1208)$ T/C polymorphism is linked to the incidence of opportunistic infections among HIV patients in South Africa (86).

In summary the relationship between chemokine receptors and the mechanisms of disease progression primarily involves the expression of CCR5, which mediates viral binding to the cell surface. Accordingly, reducing CCR5 expression on the cell surface should decrease the risk of viral exposure.

\section{T Cells Specific to HIV-1 Epitopes}

Some healthy individuals at high risk exposure or elite controllers/LTNPs harbor no protective HLA or CCR alleles that could explain their immunity to HIV. Both $\mathrm{CD}^{+}$and $\mathrm{CD}^{+}$ $\mathrm{T}$ cells can be involved in delayed progression to AIDS and suppression of viral replication in the absence of ART (Table 2). In comparison with HIV progressors, LTNPs have HIV-specific 
TABLE 2 | The influence of cell surface proteins of T cells on the outcome of HIV-1 infection.

\begin{tabular}{|c|c|c|c|c|}
\hline & Genes or products & Population & Phenotypes & References \\
\hline \multirow[t]{6}{*}{$\mathrm{CD}^{+}$} & Dominant TCR Clonotypes & Elite; LTNP & Better duration; Cross reactivity & $(87-89)$ \\
\hline & $\begin{array}{l}\text { KK10-specific TCR clonotype } \\
\text { BV27-CASSGGRRAF/J1-1 }\end{array}$ & Elite vs. Progressors (4\% vs. 20\%) & Less effective & $(87)$ \\
\hline & $\begin{array}{l}\text { KK10-specific TCR clonotype } \\
\text { BV21-CASTNRGSEQY/J2-7 }\end{array}$ & Elite vs. Progressors (4\% vs. 17.7\%) & Less effective & $(87)$ \\
\hline & Preservation of CD73 on cells & Elite & Normal function & (90) \\
\hline & Up regulation of $\mathrm{PD}-1$ & LTNPs vs. TP (16.3\% vs. 45.2\%) & Reduced CD4+ T cells; Increased VLs & $(91,92)$ \\
\hline & Increase of $\mathrm{HLA}^{+} \mathrm{G}^{+}$ & Controllers & Higher CD4+ T cells; Lower VLs & (93) \\
\hline \multirow[t]{9}{*}{$\mathrm{CD}^{+}$} & Gag293-specific TCR clonotype TRAV24 & Controller vs. treated patients (44\% vs. 13\%) & Superior functions & $(94)$ \\
\hline & Gag293-specific TCR clonotype TRBV2 & Controller vs. treated patients ( $82 \%$ vs. $28 \%)$ & Superior functions & $(94)$ \\
\hline & $\mathrm{CD}_{45 \mathrm{RA}}+\mathrm{CCR}^{-}$ & LTNPs & IFN- $\gamma$ secreting & (95) \\
\hline & Depletion of $\mathrm{CD}^{+} 3^{+}$on cells & Progressors & Reduced $\mathrm{CD} 4^{+}$T cells & (96) \\
\hline & $\begin{array}{l}\text { Frequency of Tregs of } \mathrm{CD}^{2} 5 \mathrm{RA}^{+} \mathrm{CD}^{-} 7^{-} \mathrm{CCR}^{-} \\
\mathrm{CD}^{-} \mathrm{L}^{-} \text {and } \mathrm{CD} 45 \mathrm{RA}{ }^{-} \mathrm{CD} 27^{-} \mathrm{CCR}^{-} \mathrm{CD}^{-} \mathrm{L}^{-}\end{array}$ & $\mathrm{ART}^{-}$population & Higher VLs within total CD4 ${ }^{+} T$ cells & $(97)$ \\
\hline & CTLA-4 on Tregs & Infected population & Corresponding to stages of disease & (98) \\
\hline & ICOS on Tregs & Infected population & Corresponding to stages of disease & (98) \\
\hline & Steady CD39 on Tregs & Elite & Stable CD4+ T cells; & $(98)$ \\
\hline & $\begin{array}{l}\text { Preserved } \mathrm{V} \gamma 2 \mathrm{~V} \delta 2 \\
\beta 7^{\mathrm{Hi}}\end{array}$ & $\begin{array}{l}\text { NVSs } \\
\text { Progressors }\end{array}$ & $\begin{array}{l}\text { Suppressed VLs; Higher CD56 } \\
\text { Higher risk of infection; More rapid } \\
\text { progression }\end{array}$ & $\begin{array}{l}(99) \\
(100)\end{array}$ \\
\hline
\end{tabular}

$\mathrm{CD}^{+} \mathrm{T}$ cells with superior cytotoxicity $(101,102)$, which suppress HIV replication of autologous HIV-infected $\mathrm{CD} 4^{+} \mathrm{T}$ cells in vitro $(102,103)$. These effects involve upregulation of perforin and loading of lytic granules in $\mathrm{CD}^{+} \mathrm{T}$ cells $(102,104$, 105). $\mathrm{CD}^{+} \mathrm{T}$ cells from elite controllers exhibit more sustained effector properties than those of chronic progressors (106).

$\mathrm{CD}^{+}$T-cell recognition of virus-infected cells is restricted by host major histocompatibility complex (MHC) class I. Consequently, the protective effects of HIV-specific $\mathrm{CD}^{+} \mathrm{T}$ cells in HIV-1 controllers, who have lower VLs and slower disease progression, is due in part to certain MHC class I alleles, such as HLA-B*57 and HLA-B*27. HIV-1 mutational escape, driven by the immune pressure of $\mathrm{CD}^{+}$T-cell targeting of the conserved Gag epitope, is detrimental to viral fitness in the presence of protective HLA alleles that decrease viral replicative capacity (107). For instance, the $\mathrm{N} 271 \mathrm{H}$ mutation located in the immunodominant HLA-B*27-restricted p24 Gag epitope KK10 results in a $40 \%$ reduction of infectivity relative to wild-type Gag (4). T-cell receptor (TCR) clonotypes and the avidity of CD8 ${ }^{+}$ $\mathrm{T}$ cells are also associated with anti-HIV efficacy $(87,108)$. A longitudinal study of KK10-specific $\mathrm{CD} 8^{+}$TCR repertoires in a cohort of HLA-B*2705 LTNPs suggested that these individuals could rearrange the TCR to yield high affinity for viral epitopes (88).

Many HIV progressors harboring protective alleles are unable to control HIV infection, leading researcher to attempt to characterize TCR in individuals expressing the same HLA allele but exhibiting different HIV infection phenotype. In five elite controllers and five progressors infected by virus with the KK10 epitope, quantification of KK10 epitope-specific CD8 ${ }^{+}$ $\mathrm{T}$ cells by staining with HLA-B*27-KK10 tetramer revealed no significant difference in the proportion of KK10-specific cells between the two groups (87). However, antigen-specific $\mathrm{CD}^{+}$ $\mathrm{T}$ cells from HIV-1 controllers had better functional activity, including greater potency in loading and delivery of perforin to inhibit HIV-1 replication and broader cross-recognition of HIV-1 viral variants (87). Depleting KK10-specific CD8 ${ }^{+} \mathrm{T}$ cells from bulk $\mathrm{CD}^{+} \mathrm{T}$ cells in controllers led to a $90 \%$ reduction in the inhibition of HIV replication in autologous $\mathrm{CD}^{+}{ }^{+} \mathrm{T}$ cells, indicating that immune control was mediated by a KK10specific response and demonstrating the functional importance of $\mathrm{CD}^{+} \mathrm{T}$ cells. Further detailed analysis revealed that the superior ability of $\mathrm{CD} 8^{+} \mathrm{T}$ cells in controllers was correlated with dominant TCR clonotypes. Despite considerable heterogeneity in TCR gene usage among people targeting genetically identical epitopes through genetically identical HLA alleles, dominant clonotypes of $\mathrm{KK} 10$-specific $\mathrm{CD}^{+} \mathrm{T}$ cells were diversely distributed between elite controllers and chronic progressors, as determined by TCR sequencing of cloned KK10-specific $\mathrm{CD} 8^{+} \mathrm{T}$ cells derived from sorted KK10 tetramer-positive cells. The same two clonotypes, TCRBV27-CASSGGRRAF/J1-1 and TCRBV21CASTNRGSEQY/J2-7, were identified in two subjects from elite controllers and progressors; nonetheless, the frequencies in individuals were $4 \%$ vs. $20 \%$ and $4 \%$ vs. $17.7 \%$, respectively. The capacity of these clonotypes to recognize HIV-1 and viral variants varied considerably, with the most effective immunodominant clonotypes derived from controllers (87). Superior clonotypes from controllers with the ability to cross-recognize of dominant epitope variants prevented the emergence of viral escape mutants (89).

HIV-1 infection is characterized by host immune system dysfunction represented by chronic immune activation, 
suppressed $\mathrm{T}$ lymphocyte functions, and immune exhaustion. CD39 and CD73 are an ecto-ATPase and an ecto-5'-AMP nucleotidase, respectively; both are broadly expressed by a variety of immune cells. CD39 degrades ATP and ADP to AMP, and CD73 further degrades AMP to adenosine (ADO) (109), and is therefore potently immunomodulatory (110). Down-regulation of CD73 in T cells is correlated with immune activation and functional defects in the T cells of HIV-infected people $(90,111,112)$. Preservation of HIV-specific $\mathrm{CD}_{73}{ }^{+}$ $\mathrm{CD}^{+} \mathrm{T}$ cells is a characteristic feature that distinguishes HIV elite controllers from HIV-1 progressors (90).

Antigen (Ag)-specific $\mathrm{CD}^{+} \mathrm{T}$ cells are among the major components involved in controlling HIV infection, but eventually these functional $\mathrm{CD} 8^{+} \mathrm{T}$ cells lose their antiviral activity. Inhibitory programmed death-1 (PD-1) receptor, an exhaustion marker, is also relevant to HIV disease progression $(91,92)$. Up-regulation of PD-1 is partially responsible for loss of control of virus replication due to $\mathrm{CD} 8^{+} \mathrm{T}$-cell dysfunction, e.g., reduced production of perforin and IFN- $\gamma$. PD-1 up-regulation on total and HIV-specific $\mathrm{CD} 8^{+} \mathrm{T}$ cells correlates significantly with reduced $\mathrm{CD}^{+} \mathrm{T}$ cell numbers and elevated plasma HIV-1 load in both LTNPs and TP patients. However, LTNPs have not only significantly fewer PD-1 HIV-specific CD8 ${ }^{+} \mathrm{T}$ cells than TP patients $(16.3 \%)$ vs. $45.2 \%, P<.05)(92)$, but also express significantly lower levels of PD-1 on HIV-specific CD8 ${ }^{+} \mathrm{T}$ cells $(91,92)$. Median fluorescence intensity (MFI) analysis revealed that PD-1 expression on HIV-specific $\mathrm{CD}^{+} \mathrm{T}$ cells varied among different populations of Ag-specific $\mathrm{CD} 8^{+} \mathrm{T}$ cells in comparison with donor-matched naive cells. The heterogeneity in $\mathrm{PD}-1$ expression among different virus-specific $\mathrm{CD} 8^{+} \mathrm{T}$ cell populations in elite controllers implies that the Ag-specific $\mathrm{CD}^{+} \mathrm{T}$ cells have lost their ability to fully suppress PD-1 transcription (91). The subset of CD4 and CD8 T cells expressing the non-classical HLA class Ib molecule HLA-G has regulatory properties (113). The proportion of HLA-G ${ }^{+}$HIV-1-specific CD8 T cells is higher in HIV-1 controllers than in disease progressors; the frequency of these $\mathrm{CD}^{+} \mathrm{T}$ cells is directly associated with CD4 T-cell counts and inversely correlated with VLs, indicating an association with HIV-1 immune control (93).

In the ANRS CODEX cohort, HIV controller (HIC) Gagspecific $\mathrm{CD}^{+} \mathrm{T}$ cells consistently exhibited superior IFN$\gamma$ production and degranulation capacity in comparison with long-term-treated patients (114). Gag293 peptide is the most immunoprevalent $\mathrm{CD} 4$ epitope. Using a device allowing the amplification of MHC II tetramer-positive cells in short-term primary $\mathrm{CD} 4^{+} \mathrm{T}$-cell cultures, a population of $\mathrm{CD} 4^{+}$primary $\mathrm{T}$ cells with high antigen sensitivity and high MHC II tetramer binding capacity for Gag293 peptide was identified in HICs; however, such cells were absent in ART-treated patients (114). Titration of the Gag293 peptide for intracellular cytokine staining (ICS) response confirmed the properties of Gag-specific $\mathrm{CD} 4^{+}$ $\mathrm{T}$ cells in HICs, which were distinguished from those in ARTtreated patients by their superior proliferative function and IFN$\gamma$-secreting effectors. TCR features may explain the remarkable performance of HIV-specific CD4 responses in controllers, because neither HLA genetic background nor residual virus could explain the superior activity. The high-affinity Gag293specific TCRs were cross-restricted by as many as five distinct HLA-DR alleles of diverse genetic backgrounds in HIV controllers, and both HIV controllers and ART recipients had long-term undetectable VL ( $>10$ years) and were therefore unable to drive the induction of high-affinity TCR. Analysis of the TCR $\alpha$ variable gene (TRAV) and TCR $\beta$ variable gene (TRBV) of these $\mathrm{CD}^{+}$primary $\mathrm{T}$ cells revealed biased preferential gene usage. TRAV expression in Gag293-specific $\mathrm{CD}^{+} \mathrm{T}$ cells from controllers was highly skewed, with a median of $44 \%$ of cells expressing the TRAV24, whereas this gene family was amplified at much lower levels in cells from treated patients (13\%; $P=0.037)$. TRBV2 was amplified in Gag293-specific cells from the vast majority of controllers $(82 \%$, vs. $28 \%$ in treated patients). Public clonotypes of TRAV24 and TRBV2, defined as identical CDR3 AA sequences found in at least two individuals without any mismatch, were significantly more frequent in the HIC group than in the ART group. Transfer of these public clonotypes into healthy donor $\mathrm{CD}^{+} \mathrm{T}$ cells and coculture with autologous monocyte-derived dendritic cells (MDDCs) pulsed with Gag293 conferred high antigen sensitivity and polyfunctionality, including multiple cytokine production and degranulation capacity. Thus, transduction of public clonotypes of TRAV24 and TRBV2 recapitulated key features of the controller CD4 response (94).

Harari et al. (95) reported phenotypic heterogeneity

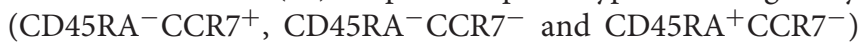
of HIV-specific CD4 $\mathrm{T}$ cells among LTNPs, representing protracted Ag exposure and low VL. Chronic stimulation with low Ag levels resulted in the appearance of memory CD4 cells with the $\mathrm{CD}^{2} 5 \mathrm{RA}^{+} \mathrm{CCR}^{-}$phenotype that secreted IFN- $\gamma$ when being stimulated with HIV-1 Gag p55; by contrast, the same population in HIV progressors had no IFN- $\gamma$-secreting activity.

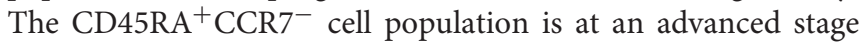
of differentiation, as evidenced by upregulation of the surface marker CD57 (95).

The typical stages of HIV infection are gradual depletion of $\mathrm{CD}^{+} \mathrm{T}$ cells, immune activation, and exhaustion. The immune regulatory molecule $\mathrm{CD} 73$ may play a crucial role in controlling HIV-1-associated immune activation. Among 36 HIV-1-positive individuals treated and not treated with ART, depletion of the ADO-producing $\mathrm{CD} 4^{+} \mathrm{CD}_{73}{ }^{+}$subset of $\mathrm{T}$ cells accounted for the loss of suppression of responder cell proliferation (96). Absolute number and frequency of $\mathrm{CD} 4^{+} \mathrm{CD} 73^{+} \mathrm{T}$ cells positively correlated with $\mathrm{CD} 4^{+} \mathrm{T}$ cell count, regardless of viral suppression, and negatively correlated with expression of CD38 (representing activated CD4T cells) and inflammatory $\mathrm{C}$ reactive protein (CRP) expression in plasma (96). T-cells of the $\mathrm{CD} 4^{+} \mathrm{CD}_{3}{ }^{+}$subset belong to the memory compartment $\left(\mathrm{CD}_{4} \mathrm{RO}^{+}\right)$and are not classified as regulatory $\mathrm{T}$ cells (Tregs) because they do not express the commonly used Treg markers CD25 and FOXP3 (96).

Tregs expressing the classic markers CD25 and FOXP3 are also involved in the coordination of immune responses and maintenance of homeostasis. Assessment of the frequency and quality of regulatory $\mathrm{T}$ cells $\left(\mathrm{CD} 4^{+} \mathrm{CD} 25^{+} \mathrm{CD} 127^{\text {low }}\right)$ from a cohort of 31 HIV-infected 
ART-naïve patients displayed dominant phenotypes by effector

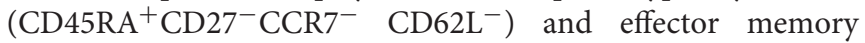
$\left(\mathrm{CD} 45 \mathrm{RA}^{-} \mathrm{CD}^{-} 7^{-} \mathrm{CCR}^{-} \mathrm{CD}^{-\mathrm{C}^{-}}{ }^{-}\right)$cells with enhanced expression of CD39, CD73, HLA-DR, and CD38, differing from $\mathrm{HIV}$-negative individuals who mainly displayed naive $\left(\mathrm{CD}_{4} 5 \mathrm{RA}^{+} \mathrm{CD}^{+} 7^{+} \mathrm{CCR}^{+} \mathrm{CD} \mathrm{CL}^{+}\right)$and central memory $\left(\mathrm{CD} 45 \mathrm{RA}^{-} \mathrm{CD}_{27}{ }^{+} \mathrm{CCR}^{+} \mathrm{CD}^{+} \mathrm{L}^{+}\right)$cells. The total number of Treg cells inversely correlated with HIV VL and positively with $\mathrm{CD} 4^{+}$count. However, among total $\mathrm{CD} 4^{+} \mathrm{T}$ cells, Treg cell frequency correlated positively with HIV-1 plasma VL (97), consistent with the frequency and phenotype of Tregs in a well-characterized larger cohort of 131 HIV-infected patients. Patients with high HIV-1 viremia and progressive disease at different stages exhibited a significant elevation in relative Treg frequency within the $\mathrm{CD} 4^{+}$compartment, whereas patients with elite status had Treg frequencies relatively comparable to those of healthy individuals (98). Two surface molecules, the cytotoxic T-lymphocyte-associated antigen 4 (CTLA-4) and inducible costimulator (ICOS), which function in controlling adaptive immune responses, were expressed at significantly higher levels in Treg cells than in healthy controls, although the levels of expression differed according to disease stage. A significant increase in CD39 expression was observed in Treg cells of patients, but not in the healthy or elite populations (98).

$\gamma \delta \mathrm{T}$ cells serve as a bridge between innate and adaptive responses (115). Quantitative changes in $\mathrm{V} \gamma 2 \mathrm{~V} \delta 2 \mathrm{~T}$ cells after HIV infection were unique among cohorts, including natural viral suppressors who have undetectable VLs for $>2$ years without ART (NVSs, $n=21$ ), HIV negative individuals (HIV-, $n=27$ ) and HIV viral controllers on ART (HIV-P, $n=25)$. The proportion of ${\mathrm{V} \delta 2^{+}}^{+}$was significantly higher among NVSs than in the HIV- and HIV-P groups. The frequency of $\mathrm{V} \gamma 2$ chains was lower among NVSs than in HIV-controls $(P=0.016)$ but higher than in HIV-P patients $(P=0.03)$, indicating that NVSs better preserved $\mathrm{V} \gamma 2 \mathrm{~V} \delta 2 \mathrm{~T}$ cells. In addition, $\mathrm{V} \gamma 2^{+}$cells of NVSs exhibited sustained function by expressing higher levels of CD56, and comparable or higher CD56 expression post isopentenyl pyrophosphate (IPP) stimulation compared to HIV- and HIV-P groups (99).

Integrin $\alpha 4 \beta 7$ promotes homing of $\mathrm{T}$ cells to gastrointestinal (GI) mucosa. $\alpha 4 \beta 7$ directs CD 4 T cells to the $\alpha 4 \beta 7$ binding site in the $\mathrm{V} 2$ region of some viruses, which facilitates their attachment to target CD4 T cells. $\alpha 4 \beta 7$ integrin expression is associated with HIV clinical outcomes (100). Remarkedly, frequencies of $\beta 7^{\mathrm{Hi}} \mathrm{CD} 4^{+} \mathrm{T}$ cells predicted $17 \%(P=0.007)$ increased risk of $\mathrm{HIV}$ acquisition and more than twice rate of CD4 T cell counts progression to $<500 / \mu l$ in a cohort of high-risk African women.

Overall, the ultimate functionality of $\mathrm{T}$ cells signifies their effect on HIV infection outcome. In disease controllers, $\mathrm{CD} 4^{+}$ and $\mathrm{CD}^{+}$specific $\mathrm{T}$ cells contain either higher frequency of the most effective clonotypes or lower frequency of the less effective clonotypes, e.g., Gag293-specific immunodominant TCR clonotype TRAV24 and TRBV2 on CD4 ${ }^{+} \mathrm{T}$ cells and the KK10-specific TCR clonotype BV27/J1-1 and BV21/J2-7 on $\mathrm{CD}^{+} \mathrm{T}$ cells, respectively. Superior function of $\mathrm{T}$ cells implies preservation of certain phenotypic or constitutive $\mathrm{T}$ cells modulated by immune regulatory molecules (mainly CD73 and
CD39) on the cell surface. In addition, certain $\mathrm{CD}^{+} \mathrm{T}$ cell phenotypes that promote HIV attachment and invasion, such as $\beta 7^{\mathrm{Hi}}$, predict the risk of infection and disease progression.

\section{B Cell-Relevant IgG Allotypes and Allelic Fc Receptors Linked to Disease Progression}

HIV-1 infection not only results in hyperactivation, dysfunction, and immune exhaustion of $\mathrm{T}$ cells, but also stimulates B-cell hyperactivation and dysfunction, reflected by hypergammaglobulinemia and lack of pathogen-specific Ab responses (116-118). In contrast to HLA alleles, the influences of genetically and phenotypically distinct B-cell populations on the progression of HIV-1 infection progression remains virtually unexplored. gp41 IgG2 Abs are present at higher levels in elite controllers than in non-controllers $(p=0.03)$ (119), and enrichment of p24 IgG1 Abs in chronic HIV-1 subtype $\mathrm{C}$ infection independently predicts low VL $(P=$ $0.04)$ and high CD4 cell counts $(P=0.004)$. Because these evaluations were adjusted for the impact of Gag-specific T-cell responses and protective HLA class I alleles, this viral control is likely to be mediated by higher levels of antibody-dependent cellular phagocytosis (ADCP) and antibody-dependent cellular cytotoxicity (ADCC), (120, 121). Overall, broadly neutralizing antibody (NAbs) responses are not particularly associated with LTNPs except in the case of glycan-dependent NAbs, which are significantly more abundant in LTNPs than in TPs $(p=$ 0.0017) (122). Over the course of infection, increasing levels of Env-specific IgG2 Abs concomitant with decreasing levels of Env-specific IgG3 Abs are associated with loss of HIV infection control (123). The associations between HIV disease progression and B-cell membrane markers such as CD39 and CD73 have been examined (124), and a few other studies investigated the relationship between HIV progression and genetically different allotypes of immunoglobulin heavy chain (GM), kappa light chain (KM) (genetic marker), and Fc receptors (FcRs) $(125,126)$. FcRs are Ab-related and surface proteins present on many leukocytes, including B lymphocytes, follicular dendritic cells, natural killer cells (NK cells), macrophages, and neutrophils (Table 3).

Assessment of plasma IgG1 and IgG2 Abs from $32 \mathrm{HIV}$ controllers and 21 non-controllers with and without protective HLA-B alleles (HLA-B*57, HLA-B*27, HLA-B* $1402+$ Cw0802 or HLA-B*52) revealed higher plasma levels of IgG1 Abs against HIV Gag (p18, p24, rp55), Pol-encoded (p32, p51, p66) proteins, and gp120 in HIV controllers. Interesting, HIV controllers not carrying a protective HLA-B allele had significantly higher levels of IgG2 against Gag protein and IgG1 against p32, whereas IgG1 levels were significantly higher in FcgRIIa-binding immune complexes from HIV non-controllers than in HIV controllers (127). Moreover, in the same group, the association between HIV-1 p24-specific IgG Abs and natural control of HIV-1 infection in individuals not carrying HLA-B*5701 was only observed in HIV controllers, but not in elite controllers or noncontrollers (>10,000 copies/mL) (128). HIV-1 p24-specific IgG Abs exhibited higher plasmacytoid dendritic cell ( $\mathrm{pDC}$ )-reactive 
TABLE 3 | B cells and B cells related Ig and FCR genotypes relevant to the outcome of HIV-1 infection.

\begin{tabular}{|c|c|c|c|}
\hline Genes or products & Population & Phenotypes & References \\
\hline Enriched gp41 lgG2 ${ }^{b}$ & Elite & Higher ADCP and ADCC & $(119)$ \\
\hline Enriched p24 lgG1 ${ }^{a}$ & Chronic subtype $\mathrm{C}$ infection & & $(120,121)$ \\
\hline Glycan-dependent NAbs & LTNPS & & $(122)$ \\
\hline $\begin{array}{l}\text { Increased Env-specific lgG2 }{ }^{b} \text { plus } \\
\text { Decreased Env-specific IgG3 }\end{array}$ & Losing infection control & & $(123)$ \\
\hline Higher lgG2 to gag; Higher lgG1 to p32 & $\begin{array}{l}\text { Controllers carrying no protective HLA-B } \\
\text { alleles }\end{array}$ & & $(127)$ \\
\hline $\begin{array}{l}\text { Increased lgG1 in FcgRlla-binding immune } \\
\text { complexes }\end{array}$ & Non-controllers & & $(127)$ \\
\hline $\lg G$ to $p 24^{a}$ & HIV controllers carrying no HLA-B`5701 & Stronger opsonophagocytosis & $(128,129)$ \\
\hline Decreased CD39/CD73 on CD20 cells & Viremic progressors & $\begin{array}{l}\text { Increased proliferation and exhaustion; Ab } \\
\text { class switch }\end{array}$ & $(124)$ \\
\hline $\begin{array}{l}\text { GM21 non-carriers within Fc } \gamma \text { RIla } R^{b} \\
\text { non-carriers at position } 131 ; \\
\text { GM21 non-carriers within Fc } \gamma \text { RIlla } V^{b} \\
\text { allele carriers at position } 158\end{array}$ & Controllers >Non-controllers & Epistasis & $(126)$ \\
\hline KM1/3-GM3/17 interaction & Caucasians (vaccine trial) & Epistasis; Risk in HIV acquisition & $(125)$ \\
\hline KM1/3-GM5/21 interaction & All participants (vaccine trial) & Epistasis; Risk in HIV acquisition & $(125)$ \\
\hline GM23+/-Fc $\gamma$ RIIla interaction & Caucasians; All participants (vaccine trial) & Epistasis; Risk in HIV acquisition & $(125)$ \\
\hline Fc $\gamma R \| l a R^{b}$ at position 131 & $\begin{array}{l}\text { Progressors (MACS cohort) (CD4 cell } \\
\text { count }<200 / \mathrm{mm} 3 \text { ) }\end{array}$ & Less affinity to IgG; Less internalization & $(130)$ \\
\hline Fc $\gamma R$ Rllla Wb; & Progressors & Higher affinity to Fc; Immune activation & $(131)$ \\
\hline Fc $\gamma R$ Rlla RR: Fc $\gamma R$ Illa FF & Progressors & & $(131)$ \\
\hline
\end{tabular}

a Protective effect deduced from multiple independent studies.

${ }^{b}$ Controversy in distribution in infected populations.

opsonophagocytosis in HIV controllers and elite controllers than in non-controllers (129).

The immune modulators CD39 and CD73 are widely expressed on a wide range of immune cells, including B cells. They are recognized as B-cell differentiation markers (132) and play critic role in B cell-mediated suppression of T-cell functions (133). CD73 is also important for initiation of Ig class switching (134) and adhesion of B cells to follicular dendritic cells in the germinal center (135); consequently, it serves as a migration marker. Kim et al. (124) reported significant down-regulation of CD39/CD73 on CD20 ${ }^{+} \mathrm{B}$ cells in 70 patients with HIV (all stages of disease) relative to 21 healthy individuals. Down-regulation of CD39/CD73 might be a characteristic of HIV infection, as expression of these proteins was not altered in the same population of $\mathrm{B}$ cells from 16 patients infected with hepatitis $\mathrm{C}$ virus (HCV). Reduced expression of CD39/CD73 was not observed at different stages of elite, LTNP, and ART patients, suggestive of correlation with disease progression (124). The authors of that study further analyzed CD39/CD73 expression across all Bcell subsets-naïve $\mathrm{B}$ cells $\left(\mathrm{CD} 21^{+}, \mathrm{CD} 27^{-}\right)$, resting memory $\mathrm{B}$ cell $\left(\mathrm{CD} 21^{+}, \mathrm{CD} 27^{+}\right)$, active memory B cell $\left(\mathrm{CD} 21^{-}, \mathrm{CD} 27^{+}\right)$, and tissue-like memory B cells $\left(\mathrm{CD} 21^{-}, \mathrm{CD} 27^{-}\right)$in dissected groups-and observed that expression of CD39/CD73 was markedly lower than in healthy individuals or ART patients, as in the case of $\mathrm{CD} 20^{+} \mathrm{B}$ cells overall. A significant difference in CD73 expression was also observed in viremic vs. aviremic patients with HIV. However, there was correlation between $\mathrm{CD}^{+}$counts and the number of $\mathrm{CD} 39^{+} \mathrm{CD}^{+} 3^{+}$co-expressing cells, while VL was not correlated with these cells (124). Reductions in the levels of CD39/CD73 on the B-cell surface were functionally correlated with increased B-cell activation and in vitro impairment of AMP consumption, as well as, Ab class switching (124).

Allotypes expressed on the constant region (Fc) of IgG heavy chain and kappa chain are designated as allotypes GM and KM. GM comprises the G1M, G2M, and G3M allotypes representing the human $\operatorname{IgG} 1, \operatorname{IgG} 2$, and IgG3 molecules. To date, $18 \mathrm{GM}$ allotypes have been identified: four G1M, one G2M, and thirteen G3M. Similarly, KM allotypes are designated as KM1, KM2, and KM3. The allotypes are inherited in fixed combinations within different populations (136). Antibody segment Fc mediates ADCP, ADCC, antibody-dependent cellmediated virus inhibition (ADCVI), and antibody-dependent complement-dependent cytotoxicity (ADCDC) via binding to the corresponding Fc receptors (Fc $\gamma s$ ) on the surface of effector monocytes, macrophages, dendritic cells, or natural killer cells. Pandey et al. (125) have identified particular GM and Fc $\gamma$ alleles that contribute, mainly epistatically, to HIV-1 acquisition and suppression. In comparison with GM21 carriers within the Fc $\gamma$ RIIa arginine $(\mathrm{R})$ noncarriers at position 131 or within the FcyRIIIa valine (V) allele carriers at position 158, GM21 noncarriers had great odds being in virus controllers $(p=$ $0.0214 ; p=0.0495$, respectively). Assessment of epistasis between 
Fc $\gamma$ RIIa and GM21 in a logistic regression model revealed a statistically significant interaction. Genotyping of the Fc $\gamma$ RIIa, FcrRIIIa, GM, and KM alleles from 777 participants in a randomized trial of recombinant adenovirus HIV-1 vaccine revealed epistatic involvement of several allotypes in the acquisition of HIV infection: KM1/3-GM3/17 in Caucasians ( $p$ $=0.0246), \mathrm{KM} 1 / 3-\mathrm{GM} 5 / 21(p=0.0016)$ in all participants, and GM23+/-Fc $\gamma$ RIIIa $(p=0.0060 ; p=0.0085)$ in all participants $(125,126)$. Accordingly, the authors proposed that the mechanisms underlying spontaneous immune control of HIV-1 might depend on the epistatic interaction between GM and HLA alleles and involve recognition of HIV antigens by allotypically disparate IgG receptors on B cells, followed by processing and presentation on the peptide-binding grooves of protective HLA alleles. To support this idea, they referenced suggestive evidence from (119) regarding the influence of HLA alleles on the magnitude of anti-gp41 IgG2 antibody responses (137).

Polymorphisms in $\mathrm{Fc} \gamma \mathrm{R}$ genes or alleles are associated with progression of HIV infection. The various IgG subclasses have different binding affinities to individual Fc receptors. An SNP of Fc $\gamma$ RIIa (CD32) resulting in histidine $(\mathrm{H})$ at amino acid position 131 yields a protein with higher IgG binding affinity than the variant with $\mathrm{R}$ at this position (138). In order to investigate the association of Fc $\gamma$ RIIa alleles with HIV disease progression, a total of 559 HIV-infected males in the Multicenter AIDS Cohort Study (MACS) were genotyped for Fc $\gamma$ RIIa. Compared to subjects with any $\mathrm{H}$ allele (i.e., $\mathrm{HH}$ or $\mathrm{HR}$ ), homozygous RR subjects were significantly more likely to have $\mathrm{CD}^{+}$cell counts $<200 / \mathrm{mm}^{3}$ (130). However, the association of Fc $\gamma$ RIIa RR alleles with HIV disease progression was not confirmed in studies of cohorts dominated by African Americans (131) or consisting entirely of African Kenyan women $(131,139)$. Measurements of the frequency of monocytes containing immune complex (IC) of FITC-labeled HIV-1 virion and polyclonal HIV-positive IgG revealed that monocytes from $\mathrm{HH}$ homozygous subjects exhibited higher rates of internalization of antibody-virion complexes. This active internalization was mediated by IgG2, as demonstrated by the observation that depletion of IgG2 from polyclonal HIV-positive IgG decreased internalization by monocytes from $\mathrm{HH}$ donors, but had little or no impact on cells from $\mathrm{RR}$ donors (130).

Another common allelic variant $\mathrm{V}$ in FcyRIIIa conferred higher affinity to Fc than allelic phenylalanine (F) (138). In a small cohort study of 59 natural HIV progressors and 43 natural virus suppressors (NVSs), the VV genotype was not found among NVSs, and was rare among uninfected controls; instead, the vast majority of $\mathrm{VV}$ carriers (95\%) were HIV progressors. The higher affinity of FcyRIIIa VV genotype induced immune activation in progressors, which was incongruent with the protective effect in GM21 noncarriersFc $\gamma$ RIIIa VV carriers (126), yet it was unclear about the corresponding GM allele in the progressors. Fc $\gamma$ RIIa alleles were not relevant to disease progression in that small cohort, although RR:FF double homozygous genotype was linked to HIV progression. Of $59 \mathrm{HIV}$ progressors, 11 had this combined genotype, vs. 1 of $40 \mathrm{NVSs}$ and 3 of $34 \mathrm{HIV}$-negative controls (131).

A handful of B-cell surface proteins, Ig, and FcR have been associated with disease progression to date. As with CD39/CD73 on $\mathrm{T}$ cells, surface proteins on $\mathrm{B}$ cells are linked with disease control via immune regulation, and the allotypes of Ig and $\mathrm{Fc} \gamma \mathrm{R}$ alleles on effector cells act epistatically on the ultimate outcome. Elevated levels IgG2 Abs are observed in both controllers and non-controllers. Accordingly, it may be necessary to carefully analyze the influence of G2M alleles and their cognate counterparts on effectors.

\section{Suppressive Effect of NK Cells on HIV Infection}

Not all HIV-1 controllers carry protective HLA-B alleles or readily exhibit $\mathrm{HIV}$-specific $\mathrm{CD}^{+}{ }^{+} \mathrm{T}$-cell responses (140). The controller status of these individuals can be explained by alternative mechanisms of immune control mediated by natural killer (NK) effector responses (Table 4).

NK cells play important roles in both the innate and adaptive immune responses. Concerning the former, NK cells recognize and quickly respond to viral-infected cells or tumor cells in the absence of Abs and MHC. NK cells inhibit viral replication in vitro by secreting chemokines that compete for binding to R5 viruses (150) or by promoting lysis of HIV-1-infected autologous $\mathrm{CD}^{+} \mathrm{T}$ cells $(151,152)$. A 3-5 years follow-up study of the relationship between NK cell function and outcome among Vietnamese intravascular drug users (IDUs) at high risk for HIV exposure indicated that NK cells contribute to protection against HIV (153). NK cells from exposed uninfected (EU) IDUs had significantly higher levels of cytokine secretion and lytic activity than unexposed controls or IDU seroconverters, although the percentage of NK cells among PBMCs did not differ among the three groups (153), supporting a role for genetic background of NK cells. Genetic protection by NK cells was also evidenced by the reduced risk of HIV infection in individuals carrying a combined genotype of HLA-B*57 and the KIR $3 \mathrm{DL} 1{ }^{*} \mathrm{~h} /{ }^{*} \mathrm{~h}$ or KIR3DL1*h/*004 alleles, which express high levels of KIR3DL1. This combined genotype was more frequent in EU individuals $(12.2 \%)$ than in individuals with primary infection $(2.7 \%)(P=$ 0.019) (141).

Activating and inhibitory receptors are present on the membranes of $\mathrm{NK}$ cells. In general, natural cytotoxicity receptors (NCRs), NKG2(CD94), and Fc $\gamma$ IIIa (CD16) are activating receptors, whereas inhibitory receptors include killer-cell immunoglobulin-like receptors (KIRs) and leukocyte inhibitory receptors (LIR). KIR receptors of NK cells are differentiated by the number of extracellular immunoglobulin domains and the length of the cytoplasmic tail: KIR2D and KIR3D have two and three extracellular domains, respectively; proteins with long intracellular tails 1-3 (L1-3) mediate inhibitory signals, whereas those with short intracellular tails (S) mediate activating signals with or without associated adaptor proteins. KIR genes appear to have variegated expression, and their corresponding cognate HLA class I ligands are highly variable. Different ethnicities have skewed distributions of KIR 
TABLE 4 | The influence of cell surface proteins of NK cells on the outcome of HIV-1 infection.

\begin{tabular}{|c|c|c|c|}
\hline Genes or products & Population & Phenotypes & References \\
\hline KIR 3DL1*h/*h or *004 + HLA-B`57 & $\begin{array}{l}\text { More frequent in exposed uninfected } \\
\text { individuals }\end{array}$ & & $(141)$ \\
\hline Increased KIR2DL2/L3/S2; Decreased KIR2DL1/S1 & Infected patients & Increased VLs & $(142)$ \\
\hline $\operatorname{KIR} 3 D L 1^{\mathrm{a}}$ & Slow progressor & Lower VLs; Strong NK responses & $(22,143,144)$ \\
\hline $\begin{array}{l}\text { KIR3DS1 } 1^{b}+H L A-B \text { Bw4-80I (irrespective of } \\
\text { HLA-B } 57 \text { or HLA-B* } 27 \text { ) }\end{array}$ & Slow progressors & $\begin{array}{l}\text { Epistasis } \\
\text { NK cell function }\end{array}$ & $\begin{array}{l}(145) \\
(146)\end{array}$ \\
\hline KIR3DS1b & Progressors & Rapid to endpoint & $(145)$ \\
\hline $\begin{array}{l}\text { HLA-C*01:02+KIR2DL2; HLA-C }{ }^{\star} 12: 02^{b}+K I R 2 D L 3 ; \\
\text { HLA-B*46:01+KIR2DL2 }\end{array}$ & CRF01_AE chronically infected Thais & Higher VLs & $(147)$ \\
\hline HLA-C*12:03+KIR2DL2; HLA-C*12:03+KIR2DS2 & CRF01_AE chronically infected Thais & Lower VLs & $(147)$ \\
\hline Increased NKp44 (CD56dim) & Clade A/D infected Ugandans & Reduced $\mathrm{CD}^{+}{ }^{+} \mathrm{T}$ cells & $(148)$ \\
\hline No induction of NKp44 Upon rlL2 stimulation & EC/LTNPS & CD4 maintenance & $(149)$ \\
\hline Lower NKp30 upon rlL2 stimulation & ECs and LTNP & & $(149)$ \\
\hline NKG2A & Infected population & $\begin{array}{l}\text { Higher VLs; Reduced CD4 }{ }^{+} \text {T cells; } \\
\text { Increased NK inhibition }\end{array}$ & (9) \\
\hline
\end{tabular}

a Protective effect deduced from multiple independent studies.

${ }^{b}$ Controversial roles in disease progress.

and HLA variants (154). KIR molecules interact specifically with HLA-A, HLA-B, or HLA-C. Bw4, a putative ligand for KIR, can be classified into the Bw4-80I (less HLA-B alleles and HLA-A alleles) and Bw4-80T (more HLA-B alleles) allotypes based on the present of isoleucine or threonine at position 80 . HLA-C1 and HLA-C2 are ligands to KIR that interact with KIR2DL2/L3/S2 and KIR2DL1/S1 respectively. The associations between KIR genes and delayed AIDS progression have been investigated $(22,155)$. NK-cell cytotoxicity is higher in LTNPs than in patients with viremic HIV and similar to that in controls, despite a reduction in the overall proportion of NK cells in these individuals (156).

The phenotypic and genotypic profiles of NK cells are associated with HIV infection progression. Increased frequency of NK cells expressing KIR2DL2/L3/S2 and decreased frequency of NK cells expressing KIR2DL1/S1 are correlated with VL in all patients (142). The alleles of KIR3DL1 encode high-expression allotypes (KIR3DL1*h), low-expression allotypes (KIR3DL1*1), and those with no cell surface expression $\left({ }^{*} 004\right)$. KIR3DL1*h has a higher affinity for Bw4-80I than Bw4-80T, resulting in greater inhibition of HIV (143) and thereby slowing the progression to AIDS via elevated NK-cell polyfunction (22). Stratification of 915 HIV-1-infected subjects from four cohorts revealed that at least part of the protection against HIV in terms of disease progression and VL could be attributed to KIR3DL1. From most protective to least protective, the alleles could be ranked KIR3DL1*h/*h or KIR3DL1*h/*004 + Bw480I $>$ KIR3DL1 ${ }^{*} 1 /{ }^{*}$ l, KIR3DL1*1/*h or KIR3DL1*1 $/{ }^{*} 004+\mathrm{Bw} 4-$ $80 \mathrm{I}>$ Bw6/Bw6 (trend $P=0.001$ ) (143). The protective $\mathrm{KIR} 3 \mathrm{DL} 1{ }^{*} \mathrm{~h} /{ }^{*} \mathrm{y}$ receptor genotype being associated with strong NK responses was inversely associated with HIV-1 Gag-specific $\mathrm{CD}^{+} \mathrm{T}$ cell responses among elite controllers (144). Because allele *004 is not expressed on the cell surface, slower progression to AIDS among individuals carrying KIR3DL1*004 + Bw4 implies a novel intracellular function for KIR3DL1* 004 or linkage disequilibrium with a neighboring locus that confers protection. The inhibition of KIR3DL1 ${ }^{*} \mathrm{~h}$ in the presence of $\mathrm{Bw} 4$ in association with slow progression to AIDS and lower VL via augmentation of NK functions seems contradictory. However, this phenomenon may demonstrate a mechanism called NK cell licensing: previous engagement of inhibitory receptor of NK cells with MHC-I molecules would allow for greater responsiveness upon subsequent activation stimuli (157). Bw4 contains the most protective HLA class I alleles, such as HLA-B*57 and HLA $B^{*} 27$, and the heightened effect of HLA-B*57 in combination with distinct KIR3DL1 groups supports the contribution of the allotypes of KIR3DL1 (143). A study of the same cohort of European- and African-Americans revealed that the activating allele KIR3DS1 is also associated with delayed progression to AIDS in conjunction with HLA-B Bw4-80I alleles, independent of the expression of the respective HLA-B Bw4-80I alleles HLA$B^{*} 57$ or HLA-B*27 (145). The protective effect was derived from an epistatic interaction between the two loci, as KIR3DS1 alone was associated with rapid progression to AIDS, and HLA-B Bw4-80I only had a protective effect in European-Americans, but no influence on African Americans, who have a lower frequency of KIR3DS1 ( $f=0.05$ vs. 0.22 in European-Americans) (145).

A KIR3DS1 protective role was observed in early HIV-1 infection when they mediated greater effector function inducing IFN- $\gamma$ and CD107a. The augmented effector activities could not be attributed to Bw4-80I because the levels of IFN- $\gamma$ and CD107a expression in NK cells did not differ among KIR3DS1 subjects with or without the Bw4-80I allele. NK cells from individuals with at least one copy of KIR3DS1 had higher IFN- $\gamma$ expression and equivalent CD107a expression in the presence of 721.221 stimulator cells lacking all MHC class I proteins (146). The protective effect of KIR3DS1, associated with slow progression to AIDS, might involve NK cell-mediated inhibition of HIV-1 replication (158). 
The effect of HLA-C-KIR2D pairs on disease outcome was recently described in a Thai cohort of ART-naive adults chronically infected with HIV CRF01_AE (147). Subjects with genotypes KIR2DL2/HLA-C*01:02, KIR2DL3/HLA-C*12:02, and KIR2DL2-HLA-B*46:01 had significantly higher VLs than subjects lacking the corresponding KIR2D. Another HLA-C1 allele, $C^{*} 12: 03$, had supressive effect on VLs when paired with both KIR2DL2 and KIR2DS2.

Significantly increased expression of NKp44, an NCRs on NK cells, was detected in CD56dim NK cells in HIV-1 Clade A- or Clade D-infected Ugandans, and the phenotypic change correlated inversely with absolute CD4 counts, indirectly supporting a role for this receptor in disease progression (148). Upon stimulation by rIL2, expression of NKp44 on NK cells in EC/LTNP was not induced (149), sharply decreasing the ability of NK cells to kill target cells in vitro, in contrast to the situation in antiretroviral-treated aviremic progressor patients (TAPPs). The marked impairment of NKp44 inducibility distinguishes HIV controllers (LTNPs/ECs) from progressors, as the lack of NKp44 induction may be related to CD4 maintenance (149). When activated by rIL2, NKp30 was modulated to lower levels in ECs and LTNPs vs. healthy donors (HDs), whereas no induction of NKp30 expression was observed in TAPPs (149). Induction of NKG2D receptor positively influenced ADCC responses, as evidenced by the observation that blockade of NKG2D receptor significantly decreased ADCC activity against infected cells; according to the authors of that study, however, the NKG2D phenotype might be influenced by viral rather than host factors (159). The inhibitory cell receptor NKG2A on NK cells was correlated with VL, CD4 count, and outcome postinfection, as described above in the in HLA section (9). The deleterious effect of NKG2A was mediated through expression of HLA-E, the natural ligand of NKG2A. Enhancement of HLA-E expression due to binding of a signal peptide derived from the leader sequence of HLA-A, -B, and -C molecules promotes NKG2A-mediated NK-cell (and/or T-cell) inhibition. The negative effect of HLA-A on HIV control was exacerbated by HLA-B -21M, which favors NKG2A-mediated NK cell licensing.

In summary, NK cells may impact disease progression independently of, or epistatically with, HLA molecules. Both inhibition and activation of NK cell receptors play roles in control of HIV infection.

\section{DISCUSSION}

The outcome of HIV-1 infection varies dramatically among infected people. The mechanisms underlying slow progression to AIDS in LTNP, especially in elite controllers, has attached a great deal of research interest and inspired numerous studies. A tremendous effort has already been made to solve this puzzle, and the results may eventually bring about a means to conquer AIDS.

Extended studies have revealed that multiple factors are involved in determining HIV-1 disease outcome. In addition to HLA variations, which account for up to $25 \%$ of elite controllers, many other elements involving various types of immune cells can contribute to effective immunity to HIV-1. The patterns in which controllers restrain HIV infection vary across populations. Some HLA alleles, for example HLA-B*57, slow disease progression by improving presentation of $\mathrm{HIV}-1$ antigens. Other variants, such as CCR5 $\Delta 32$, allow hosts to resist HIV-1 infection by eliminating components necessary for virus invasion. In addition, some controllers have immune cells, such as $\mathrm{CD}^{+} \mathrm{T}$ cells, with superior ability to protect against viruses. In addition, infected individuals may be categorized differently due to intrinsic features of Igs and FcRs on effector cells.

Some protective or deleterious genetic factors are restricted to certain ethnicities and populations, illustrating the importance of genetic identity. For example, CCR5 $\Delta 32$ is most prevalent in Caucasians. However, genetically inherited immune traits are not the exclusive influence on outcome; in addition, phenotypic traits of immune cells also have an impact on infection status. The preservation of immunoregulatory molecule CD73 on immune cells is a hallmark of slow progressors. Notably in this regard, it is not uncommon for a gene to play contradictory roles in HIV infection, such genes distribute almost each compartment of immune system (Tables 1, 3, 4), which proposes comprehensive association studies.

In light of the modern trend toward personalized medicine, it is especially important to thoroughly investigate how HIV1 disease is controlled in vivo. To date, the complexity of the host immune system is the major challenge in profiling the multifaceted and multifactorial contributions to HIV-1 disease outcome. Successful elucidation of these associations could guide optimal HIV-1 disease treatment and vaccine design within specified genetic populations. The greater efficacy of the RV144 vaccine in the HLA-A*02 population highlights the feasibility of personalized vaccine design.

Assessment of cross-sections within individual immune cells is difficult and relies on complete and precise bioinformation at different stages of disease. The corpus of previous studies using conventional genotyping methods, particularly those spanning more than 10 years, is relatively limited. With the advent of new technologies, such as genome-wide association studies (GWAS) and whole genome sequencing (WGS), the landscapes of entire gene networks can be elucidated. Recently developed single-cell genome sequencing will allow researchers to establish a high-resolution view of the genes involved, and advances in bioinformatics will provide a powerful tool for efficiently processing the huge amount of information produced by these experiments. It is possible that the puzzles described in this review will be solved in the future following the evolution of sophisticated technologies.

\section{AUTHOR CONTRIBUTIONS}

LL and YL wrote the manuscript, and LL and MG revised the manuscript. All authors have made intellectual contributions to the work and approved it for publication.

\section{FUNDING}

The study was supported by grant AI112546 (MG) from the National Institute of Allergy and Infectious Diseases (NIAID), National Instiutes of Health (NIH). 


\section{REFERENCES}

1. Hubert JB, Burgard M, Dussaix E, Tamalet C, Deveau C, Le Chenadec J, et al. Natural history of serum HIV-1 RNA levels in 330 patients with a known date of infection. The SEROCO Study Group. AIDS (2000) 14:123-31. doi: 10.1097/00002030-200001280-00007

2. Deeks SG, Walker BD. Human immunodeficiency virus controllers: mechanisms of durable virus control in the absence of antiretroviral therapy. Immunity (2007) 27:406-16. doi: 10.1016/j.immuni.2007.08.010

3. Lyles RH, Munoz A, Yamashita TE, Bazmi H, Detels R, Rinaldo CR, et al. Natural history of human immunodeficiency virus type 1 viremia after seroconversion and proximal to AIDS in a large cohort of homosexual men. Multicenter AIDS Cohort Study. J Infect Dis. (2000) 181:872-80. doi: $10.1086 / 315339$

4. Bailey JR, O'Connell K, Yang HC, Han Y, Xu J, Jilek B, et al. Transmission of human immunodeficiency virus type 1 from a patient who developed AIDS to an elite suppressor. J Virol. (2008) 82:7395-410. doi: 10.1128/JVI.00 800-08

5. Buckheit RW III, Allen TG, Alme A, Salgado M, O'Connell KA, Huculak $S$, et al. Host factors dictate control of viral replication in two HIV1 controller/chronic progressor transmission pairs. Nat Commun. (2012) 3:716. doi: $10.1038 /$ ncomms 1697

6. Kwong PD, Chuang GY, DeKosky BJ, Gindin T, Georgiev IS, Lemmin T, et al. Antibodyomics: bioinformatics technologies for understanding B-cell immunity to HIV-1. Immunol Rev. (2017) 275:108-28. doi: $10.1111 /$ imr.12480

7. Goulder PJ, Walker BD. HIV and HLA class I: an evolving relationship. Immunity (2012) 37:426-40. doi: 10.1016/j.immuni.2012.09.005

8. Carrington M, O'Brien SJ. The influence of HLA genotype on AIDS. Annu Rev Med. (2003) 54:535-51. doi: 10.1146/annurev.med.54.101601.152346

9. Ramsuran V, Naranbhai V, Horowitz A, Qi Y, Martin MP, Yuki Y, et al. Elevated HLA-A expression impairs HIV control through inhibition of NKG2A-expressing cells. Science (2018) 359:86-90. doi: $10.1126 /$ science.aam 8825

10. Migueles SA, Sabbaghian MS, Shupert WL, Bettinotti MP, Marincola FM, Martino L, et al. HLA B*5701 is highly associated with restriction of virus replication in a subgroup of HIV-infected long term nonprogressors. Proc Natl Acad Sci USA. (2000) 97:2709-14. doi: 10.1073/pnas.050567397

11. Altfeld M, Addo MM, Rosenberg ES, Hecht FM, Lee PK, Vogel $\mathrm{M}$, et al. Influence of HLA-B57 on clinical presentation and viral control during acute HIV-1 infection. AIDS (2003) 17:2581-91. doi: 10.1097/00002030-200312050-00005

12. Leszczyszyn-Pynka M, Aksak-Was B, Urbanska A, Parczewski M. Protective effect of HLA-B*5701 and HLA-C-35 genetic variants in HIV-positive caucasians from Northern Poland. PLoS ONE (2015) 10:e0127867. doi: 10.1371 /journal.pone. 0127867

13. Fellay J, Ge D, Shianna KV, Colombo S, Ledergerber B, Cirulli ET, et al. Common genetic variation and the control of HIV-1 in humans. PLoS Genet. (2009) 5:e1000791. doi: 10.1371/journal.pgen.1000791

14. Carrington $\mathrm{M}$, Walker $\mathrm{BD}$. Immunogenetics of spontaneous control of HIV. Annu Rev Med. (2012) 63:131-45. doi: 10.1146/annurev-med-062909-130018

15. Dominguez-Molina B, Tarancon-Diez L, Hua S, Abad-Molina C, RodriguezGallego E, Machmach K, et al. HLA-B*57 and IFNL4-related polymorphisms are associated with protection against HIV-1 disease progression in controllers. Clin Infect Dis. (2017) 64:621-8. doi: 10.1093/cid/ciw833

16. McLaren PJ, Ripke S, Pelak K, Weintrob AC, Patsopoulos NA, Jia X, et al. Fine-mapping classical HLA variation associated with durable host control of HIV-1 infection in African Americans. Hum Mol Genet. (2012) 21:4334-47. doi: $10.1093 / \mathrm{hmg} / \mathrm{dds} 226$

17. Pereyra F, Addo MM, Kaufmann DE, Liu Y, Miura T, Rathod A, et al. Genetic and immunologic heterogeneity among persons who control HIV infection in the absence of therapy. J Infect Dis. (2008) 197:563-71. doi: $10.1086 / 526786$

18. Leitman EM, Willberg CB, De Burgh-Thomas A, Streeck H, Goulder PJ, Matthews PC. Subdominant Gag-specific anti-HIV efficacy in an HLA-B*57-positive elite controller. AIDS (2016) 30:972-4. doi: 10.1097/QAD.0000000000001022
19. Kosmrlj A, Read EL, Qi Y, Allen TM, Altfeld M, Deeks SG, et al. Effects of thymic selection of the T-cell repertoire on HLA class I-associated control of HIV infection. Nature (2010) 465:350-4. doi: 10.1038/nature08997

20. Streeck H, Lichterfeld M, Alter G, Meier A, Teigen N, Yassine-Diab B, et al. Recognition of a defined region within p24 gag by $\mathrm{CD} 8+\mathrm{T}$ cells during primary human immunodeficiency virus type 1 infection in individuals expressing protective HLA class I alleles. J Virol. (2007) 81:7725-31. doi: 10.1128/JVI.00708-07

21. Schellens IM, Spits HB, Navis M, Westerlaken GH, Nanlohy NM, Coffeng LE, et al. Differential characteristics of cytotoxic T lymphocytes restricted by the protective HLA alleles $\mathrm{B}^{*} 27$ and $\mathrm{B}^{*} 57$ in HIV-1 infection. J Acquir Immune Defic Syndr. (2014) 67:236-45. doi: 10.1097/QAI.0000000000000324

22. Kamya P, Boulet S, Tsoukas CM, Routy JP, Thomas R, Cote P, et al. Receptorligand requirements for increased NK cell polyfunctional potential in slow progressors infected with HIV-1 coexpressing KIR3DL1*h/* $\mathrm{y}$ and HLAB*57. J Virol. (2011) 85:5949-60. doi: 10.1128/JVI.02652-10

23. Kaslow RA, Rivers C, Tang J, Bender TJ, Goepfert PA, El Habib R, et al. Polymorphisms in HLA class I genes associated with both favorable prognosis of human immunodeficiency virus (HIV) type 1 infection and positive cytotoxic T-lymphocyte responses to ALVACHIV recombinant canarypox vaccines. J Virol. (2001) 75:8681-9. doi: 10.1128/JVI.75.18.8681-8689.2001

24. Hendel H, Caillat-Zucman S, Lebuanec H, Carrington M, O’Brien S, Andrieu JM, et al. New class I and II HLA alleles strongly associated with opposite patterns of progression to AIDS. J Immunol. (1999) 162:6942-6.

25. den Uyl D, van der Horst-Bruinsma IE, van Agtmael M. Progression of HIV to AIDS: a protective role for HLA-B27? AIDS Rev. (2004) 6:89-96.

26. Naruto T, Gatanaga H, Nelson G, Sakai K, Carrington M, Oka S, et al. HLA class I-mediated control of HIV-1 in the Japanese population, in which the protective HLA-B*57 and HLA-B*27 alleles are absent. J Virol. (2012) 86:10870-2. doi: 10.1128/JVI.00689-12

27. Murakoshi H, Akahoshi T, Koyanagi M, Chikata T, Naruto T, Maruyama $\mathrm{R}$, et al. Clinical control of HIV-1 by cytotoxic T cells specific for multiple conserved epitopes. J Virol. (2015) 89:5330-9. doi: 10.1128/JVI.00020-15

28. Lazaryan A, Song W, Lobashevsky E, Tang J, Shrestha S, Zhang K, et al. Human leukocyte antigen class I supertypes and HIV-1 control in African Americans. J Virol. (2010) 84:2610-7. doi: 10.1128/JVI.01962-09

29. Mori M, Wichukchinda N, Miyahara R, Rojanawiwat A, Pathipvanich P, Maekawa T, et al. HLA-B*35: 05 is a protective allele with a unique structure among HIV-1 CRF01_AE-infected Thais, in whom the B*57 frequency is low. AIDS (2014) 28:959-67. doi: 10.1097/QAD.0000000000000206

30. Tiemessen CT, Paximadis M, Minevich G, Winchester R, Shalekoff S, Gray GE, et al. Natural killer cell responses to HIV-1 peptides are associated with more activating KIR genes and HLA-C genes of the $\mathrm{C} 1$ allotype. J Acquir Immune Defic Syndr. (2011) 57:181-9. doi: 10.1097/QAI.0b013e3182174a76

31. Chikata T, Tran GV, Murakoshi H, Akahoshi T, Qi Y, Naranbhai V, et al. HLA class I-mediated HIV-1 control in Vietnamese infected with HIV-1 subtype A/E. J Virol. (2018) 92:e01749-17. doi: 10.1128/JVI.01749-17

32. Lin Z, Kuroki K, Kuse N, Sun X, Akahoshi T, Qi Y, et al. HIV-1 control by NK cells via reduced interaction between KIR2DL2 and HLA-C( *)12:02/C( *)14:03. Cell Rep. (2016) 17:2210-20. doi: 10.1016/j.celrep.2016.10.075

33. Apps R, Qi Y, Carlson JM, Chen H, Gao X, Thomas R, et al. Influence of HLA-C expression level on HIV control. Science (2013) 340:87-91. doi: $10.1126 /$ science. 1232685

34. Thomas R, Apps R, Qi Y, Gao X, Male V, O’HUigin C, et al. HLA-C cell surface expression and control of HIV/AIDS correlate with a variant upstream of HLA-C. Nat Genet. (2009) 41:1290-4. doi: 10.1038/ng.486

35. Kulkarni S, Savan R, Qi Y, Gao X, Yuki Y, Bass SE, et al. Differential microRNA regulation of HLA-C expression and its association with HIV control. Nature (2011) 472:495-8. doi: 10.1038/nature09914

36. Kulpa DA, Collins KL. The emerging role of HLA-C in HIV-1 infection. Immunology (2011) 134:116-22. doi: 10.1111/j.1365-2567.2011.03474.x

37. Blais ME, Dong T, Rowland-Jones S. HLA-C as a mediator of natural killer and T-cell activation: spectator or key player? Immunology (2011) 133:1-7. doi: 10.1111/j.1365-2567.2011.03422.x

38. Blais ME, Zhang Y, Rostron T, Griffin $\mathrm{H}$, Taylor $\mathrm{S}$, Xu K, et al. High frequency of HIV mutations associated with HLA-C suggests enhanced HLA-C-restricted CTL selective pressure associated with 
an AIDS-protective polymorphism. J Immunol. (2012) 188:4663-70. doi: 10.4049/jimmunol.1103472

39. Catano G, Kulkarni H, He W, Marconi VC, Agan BK, Landrum M, et al. HIV-1 disease-influencing effects associated with ZNRD1, HCP5 and HLA-C alleles are attributable mainly to either HLA-A 10 or HLA-B*57 alleles. PLoS ONE (2008) 3:e3636. doi: 10.1371/journal.pone.0003636

40. Corrah TW, Goonetilleke N, Kopycinski J, Deeks SG, Cohen MS, Borrow P, et al. Reappraisal of the relationship between the HIV-1protective single-nucleotide polymorphism 35 kilobases upstream of the HLA-C gene and surface HLA-C expression. J Virol. (2011) 85:3367-74. doi: 10.1128/JVI.02276-10

41. Shepherd BL, Ferrand R, Munyati S, Folkard S, Boyd K, Bandason T, et al. HLA correlates of long-term survival in vertically infected HIV1-positive adolescents in Harare, Zimbabwe. AIDS Res Hum Retroviruses (2015) 31:504-7. doi: 10.1089/aid.2014.0338

42. Selvaraj P, Swaminathan S, Alagarasu K, Raghavan S, Narendran G, Narayanan P. Association of human leukocyte antigen-A11 with resistance and B40 and DR2 with susceptibility to HIV-1 infection in south India. J Acquir Immune Defic Syndr. (2006) 43:497-9. doi: 10.1097/01.qai.0000233312.36226.76

43. Koehler RN, Walsh AM, Saathoff E, Tovanabutra S, Arroyo MA, Currier JR, et al. Class I HLA-A*7401 is associated with protection from HIV-1 acquisition and disease progression in Mbeya, Tanzania. J Infect Dis. (2010) 202:1562-6. doi: 10.1086/656913

44. Chaudhari DV, Chavan VR, Ahir SP, Kerkar SC, Mehta PR, Mania-Pramanik J. Human leukocyte antigen B distribution in HIV discordant cohort from India. Immunol Lett. (2013) 156:1-6. doi: 10.1016/j.imlet.2013.09.002

45. Wright JK, Naidoo VL, Brumme ZL, Prince JL, Claiborne DT, Goulder PJ, et al. Impact of HLA-B*81-associated mutations in HIV-1 Gag on viral replication capacity. J Virol. (2012) 86:3193-9. doi: 10.1128/JVI.06682-11

46. Leitman EM, Willberg CB, Tsai MH, Chen H, Buus S, Chen F, et al. HLAB*14:02-Restricted Env-specific CD8(+) T-cell activity has highly potent antiviral efficacy associated with immune control of HIV infection. J Virol. (2017) 91:e00544-17. doi: 10.1128/JVI.00544-17

47. Kawashima Y, Kuse N, Gatanaga H, Naruto T, Fujiwara M, Dohki S, et al. Long-term control of HIV-1 in hemophiliacs carrying slow-progressing allele HLA-B*5101. J Virol. (2010) 84:7151-60. doi: 10.1128/JVI.00171-10

48. MacDonald KS, Embree J, Njenga S, Nagelkerke NJ, Ngatia I, Mohammed $Z$, et al. Mother-child class I HLA concordance increases perinatal human immunodeficiency virus type 1 transmission. J Infect Dis. (1998) 177:551-6. doi: $10.1086 / 514243$

49. Gartland AJ, Li S, McNevin J, Tomaras GD, Gottardo R, Janes H, et al. Analysis of HLA A*02 association with vaccine efficacy in the RV144 HIV-1 vaccine trial. J Virol. (2014) 88:8242-55. doi: 10.1128/JVI.01164-14

50. Farquhar C, Rowland-Jones S, Mbori-Ngacha D, Redman M, Lohman B, Slyker J, et al. Human leukocyte antigen (HLA) B*18 and protection against mother-to-child HIV type 1 transmission. AIDS Res Hum Retroviruses (2004) 20:692-7. doi: $10.1089 / 0889222041524616$

51. Tang J, Tang S, Lobashevsky E, Myracle AD, Fideli U, Aldrovandi G, et al. Favorable and unfavorable HLA class I alleles and haplotypes in Zambians predominantly infected with clade $\mathrm{C}$ human immunodeficiency virus type 1 . J Virol. (2002) 76:8276-84. doi: 10.1128/JVI.76.16.8276-8284.2002

52. Mann JK, Byakwaga H, Kuang XT, Le AQ, Brumme CJ, Mwimanzi P, et al. Ability of HIV-1 Nef to downregulate CD4 and HLA class I differs among viral subtypes. Retrovirology (2013) 10:100. doi: 10.1186/1742-4690$10-100$

53. Collins KL, Chen BK, Kalams SA, Walker BD, Baltimore D. HIV-1 Nef protein protects infected primary cells against killing by cytotoxic $\mathrm{T}$ lymphocytes. Nature (1998) 391:397-401. doi: 10.1038/34929

54. Gao X, O’Brien TR, Welzel TM, Marti D, Qi Y, Goedert JJ, et al. HLA-B alleles associate consistently with HIV heterosexual transmission, viral load, and progression to AIDS, but not susceptibility to infection. AIDS (2010) 24:1835-40. doi: 10.1097/QAD.0b013e32833c3219

55. Kaslow RA, Duquesnoy R, VanRaden M, Kingsley L, Marrari M, Friedman $\mathrm{H}$, et al. A1, Cw7, B8, DR3 HLA antigen combination associated with rapid decline of T-helper lymphocytes in HIV-1 infection. A report from the Multicenter AIDS Cohort Study. Lancet (1990) 335:927-30. doi: 10.1016/0140-6736(90)90995-H
56. Kloverpris HN, Adland E, Koyanagi M, Stryhn A, Harndahl M, Matthews PC, et al. HIV subtype influences HLA-B*07:02-associated HIV disease outcome. AIDS Res Hum Retroviruses (2014) 30:468-75. doi: 10.1089/aid.2013.0197

57. Huang J, Goedert JJ, Sundberg EJ, Cung TD, Burke PS, Martin MP, et al. HLA-B* $35-\mathrm{Px}$-mediated acceleration of HIV-1 infection by increased inhibitory immunoregulatory impulses. J Exp Med. (2009) 206:2959-66. doi: 10.1084/jem.20091386

58. Gao X, Nelson GW, Karacki P, Martin MP, Phair J, Kaslow R, et al. Effect of a single amino acid change in MHC class I molecules on the rate of progression to AIDS. N Engl J Med. (2001) 344:1668-75. doi: 10.1056/NEJM200105313442203

59. Olvera A, Ganoza C, Perez-Alvarez S, Hildebrand W, Sanchez J, Brander C. HLA-B*35-PX and HLA-B*35-PY subtype differentiation does not predict observed differences in level of HIV control in a Peruvian MSM cohort. AIDS (2014) 28:2323-5. doi: 10.1097/QAD.0000000000000403

60. Willberg CB, Garrison KE, Jones RB, Meiklejohn DA, Spotts G, Liegler TJ, et al. Correction: rapid progressing allele HLA-B35 Px restricted antiHIV-1 CD8+ T cells recognize vestigial CTL epitopes. PLoS ONE (2016) 11:e0160293. doi: 10.1371/journal.pone.0160293

61. Matthews PC, Koyanagi M, Kloverpris HN, Harndahl M, Stryhn A, Akahoshi T, et al. Differential clade-specific HLA-B*3501 association with HIV-1 disease outcome is linked to immunogenicity of a single Gag epitope. J Virol. (2012) 86:12643-54. doi: 10.1128/JVI.01381-12

62. Juarez-Molina CI, Valenzuela-Ponce H, Avila-Rios S, Garrido-Rodriguez D, Garcia-Tellez T, Soto-Nava M, et al. Impact of HLA-B*35 subtype differences on HIV disease outcome in Mexico. AIDS (2014) 28:1687-90. doi: 10.1097/QAD.0000000000000322

63. Carrington M, Nelson GW, Martin MP, Kissner T, Vlahov D, Goedert JJ, et al. HLA and HIV-1: heterozygote advantage and $\mathrm{B}^{*} 35-\mathrm{Cw}^{*} 04$ disadvantage. Science (1999) 283:1748-52. doi: 10.1126/science.283.5408.1748

64. Rajapaksa US, Li D, Peng YC, McMichael AJ, Dong T, Xu XN. HLA-B may be more protective against HIV-1 than HLA-A because it resists negative regulatory factor (Nef) mediated down-regulation. Proc Natl Acad Sci USA. (2012) 109:13353-8. doi: 10.1073/pnas.1204199109

65. Hardie RA, Luo M, Bruneau B, Knight E, Nagelkerke NJ, Kimani J, et al. Human leukocyte antigen-DQ alleles and haplotypes and their associations with resistance and susceptibility to HIV-1 infection. AIDS (2008) 22:807-16. doi: 10.1097/QAD.0b013e3282f51b71

66. Achord AP, Lewis RE, Brackin MN, Henderson H, Cruse JM. HIV-1 disease association with HLA-DQ antigens in African Americans and Caucasians. Pathobiology (1996) 64:204-8. doi: 10.1159/000164049

67. Rallon N, Restrepo C, Vicario JL, Del Romero J, Rodriguez C, GarciaSamaniego J, et al. Human leucocyte antigen (HLA)-DQB1*03:02 and HLA$\mathrm{A}^{*}$ 02:01 have opposite patterns in their effects on susceptibility to HIV infection. HIV Med. (2017) 18:587-94. doi: 10.1111/hiv.12494

68. Raghavan S, Selvaraj P, Swaminathan S, Alagarasu K, Narendran G, Narayanan PR. Haplotype analysis of HLA-A, -B antigens and -DRB1 alleles in south Indian HIV-1-infected patients with and without pulmonary tuberculosis. Int J Immunogenet. (2009) 36:129-33. doi: 10.1111/j.1744-313X.2009.00835.x

69. Vesa J, Chaillon A, Wagner GA, Anderson CM, Richman DD, Smith DM, et al. Increased HIV-1 superinfection risk in carriers of specific human leukocyte antigen alleles. AIDS (2017) 31:1149-58. doi: 10.1097/QAD.0000000000001445

70. Samson M, Libert F, Doranz BJ, Rucker J, Liesnard C, Farber CM, et al. Resistance to HIV-1 infection in caucasian individuals bearing mutant alleles of the CCR-5 chemokine receptor gene. Nature (1996) 382:722-5. doi: $10.1038 / 382722 \mathrm{a} 0$

71. Dean M, Carrington M, Winkler C, Huttley GA, Smith MW, Allikmets $\mathrm{R}$, et al. Genetic restriction of HIV-1 infection and progression to AIDS by a deletion allele of the CKR5 structural gene. Hemophilia Growth and Development Study, Multicenter AIDS Cohort Study, Multicenter Hemophilia Cohort Study, San Francisco City Cohort, ALIVE Study. Science (1996) 273:1856-62. doi: 10.1126/science.273.5283.1856

72. Huang Y, Paxton WA, Wolinsky SM, Neumann AU, Zhang L, He T, et al. The role of a mutant CCR5 allele in HIV-1 transmission and disease progression. Nat Med. (1996) 2:1240-3. doi: 10.1038/nm1196-1240 
73. Borinskaya SA, Kozhekbaeva Zh M, Zalesov AV, Olseeva EV, Maksimov AR, Kutsev SI, et al. Risk of HIV infection and lethality are decreased in CCR5del32 heterozygotes: focus nosocomial infection study and metaanalysis. Acta Naturae (2012) 4:42-52.

74. Juhasz E, Beres J, Kanizsai S, Nagy K. The consequence of a founder effect: CCR5-32, CCR2-64I and SDF1-3'A polymorphism in Vlach Gypsy population in Hungary. Pathol Oncol Res. (2012) 18:177-82. doi: 10.1007/s12253-011-9425-4

75. Hutter G, Nowak D, Mossner M, Ganepola S, Mussig A, Allers K, et al. Longterm control of HIV by CCR5 Delta32/Delta32 stem-cell transplantation. $N$ Engl J Med. (2009) 360:692-8. doi: 10.1056/NEJMoa0802905

76. McDermott DH, Zimmerman PA, Guignard F, Kleeberger CA, Leitman SF, Murphy PM. CCR5 promoter polymorphism and HIV-1 disease progression. Multicenter AIDS Cohort Study (MACS) Lancet (1998) 352:866-70. doi: 10.1016/S0140-6736(98)04158-0

77. Singh KK, Barroga CF, Hughes MD, Chen J, Raskino C, McKinney $\mathrm{RE}$, et al. Genetic influence of CCR5, CCR2, and SDF1 variants on human immunodeficiency virus 1 (HIV-1)-related disease progression and neurological impairment, in children with symptomatic HIV-1 infection. J Infect Dis. (2003) 188:1461-72. doi: 10.1086/379038

78. Smith MW, Dean M, Carrington M, Winkler C, Huttley GA, Lomb DA, et al. Contrasting genetic influence of CCR2 and CCR5 variants on HIV1 infection and disease progression. Hemophilia Growth and Development Study (HGDS), Multicenter AIDS Cohort Study (MACS), Multicenter Hemophilia Cohort Study (MHCS), San Francisco City Cohort (SFCC), ALIVE Study. Science (1997) 277:959-65. doi: 10.1126/science.277.5328.959

79. Shrestha S, Strathdee SA, Galai N, Oleksyk T, Fallin MD, Mehta S, et al. Behavioral risk exposure and host genetics of susceptibility to HIV-1 infection. J Infect Dis. (2006) 193:16-26. doi: 10.1086/498532

80. Qidwai T, Khan MY. Impact of genetic variations in C-C chemokine receptors and ligands on infectious diseases. Hum Immunol. (2016) 77:96171. doi: 10.1016/j.humimm.2016.06.010

81. Li H, Liu TJ, Hong ZH. Gene polymorphisms in CCR5, CCR2, SDF1 and RANTES among Chinese Han population with HIV-1 infection. Infect Genet Evol. (2014) 24:99-104. doi: 10.1016/j.meegid.2014.03.009

82. Gupta A, Padh H. Analysis of CCR5 and SDF-1 genetic variants and HIV infection in Indian population. Int J Immunogenet. (2015) 42:270-8. doi: 10.1111/iji.12215

83. Blanpain C, Lee B, Tackoen M, Puffer B, Boom A, Libert F, et al. Multiple nonfunctional alleles of CCR5 are frequent in various human populations. Blood (2000) 96:1638-45.

84. Deshmane SL, Kremlev S, Amini S, Sawaya BE. Monocyte chemoattractant protein-1 (MCP-1): an overview. J Interferon Cytokine Res. (2009) 29:313-26. doi: $10.1089 /$ jir.2008.0027

85. Nakayama EE, Tanaka Y, Nagai Y, Iwamoto A, Shioda T. A CCR2-V64I polymorphism affects stability of CCR2A isoform. AIDS (2004) 18:729-38. doi: 10.1097/00002030-200403260-00003

86. Samie A, Dzhivhuho GA, Nangammbi TC. Distribution of CXCR2 +1208 T/C gene polymorphisms in relation to opportunistic infections among HIVinfected patients in Limpopo Province, South Africa. Genet Mol Res. (2014) 13:7470-9. doi: 10.4238/2014.September.12.13

87. Chen H, Ndhlovu ZM, Liu D, Porter LC, Fang JW, Darko S, et al. TCR clonotypes modulate the protective effect of HLA class I molecules in HIV-1 infection. Nat Immunol. (2012) 13:691-700. doi: 10.1038/ni.2342

88. van Bockel DJ, Price DA, Munier ML, Venturi V, Asher TE, Ladell K, et al. Persistent survival of prevalent clonotypes within an immunodominant HIV gag-specific CD8+ T cell response. J Immunol. (2011) 186:359-71. doi: 10.4049/jimmunol.1001807

89. Ladell K, Hashimoto M, Iglesias MC, Wilmann PG, McLaren JE, Gras $\mathrm{S}$, et al. A molecular basis for the control of preimmune escape variants by HIV-specific CD8+ T cells. Immunity (2013) 38:425-36. doi: 10.1016/j.immuni.2012.11.021

90. Carriere M, Lacabaratz C, Kok A, Benne C, Jenabian MA, Casartelli N, et al. HIV "elite controllers" are characterized by a high frequency of memory CD8 + CD73 + T cells involved in the antigen-specific CD8 + T-cell response. J Infect Dis. (2014) 209:1321-30. doi: 10.1093/infdis/jit643

91. Youngblood B, Noto A, Porichis F, Akondy RS, Ndhlovu ZM, Austin JW, et al. Cutting edge: prolonged exposure to HIV reinforces a poised epigenetic program for PD-1 expression in virus-specific CD8 T cells. J Immunol. (2013) 191:540-4. doi: 10.4049/jimmunol.1203161

92. Zhang JY, Zhang Z, Wang X, Fu JL, Yao J, Jiao Y, et al. PD-1 up-regulation is correlated with HIV-specific memory CD8+ T-cell exhaustion in typical progressors but not in long-term nonprogressors. Blood (2007) 109:4671-8. doi: 10.1182/blood-2006-09-044826

93. Vigano S, Negron JJ, Tse S, Chowdhury FZ, Lichterfeld M, Yu XG. HLAG+ HIV-1-specific CD8 + T cells are associated with HIV-1 immune control. AIDS (2017) 31:207-12. doi: 10.1097/QAD.0000000000001326

94. Benati D, Galperin M, Lambotte O, Gras S, Lim A, Mukhopadhyay M, et al. Public T cell receptors confer high-avidity CD4 responses to HIV controllers. J Clin Invest. (2016) 126:2093-108. doi: 10.1172/JCI83792

95. Harari A, Vallelian F, Pantaleo G. Phenotypic heterogeneity of antigenspecific CD4 T cells under different conditions of antigen persistence and antigen load. Eur J Immunol. (2004) 34:3525-33. doi: 10.1002/eji.200425324

96. Schuler PJ, Macatangay BJ, Saze Z, Jackson EK, Riddler SA, Buchanan $\mathrm{WG}$, et al. CD4 $(+) \mathrm{CD} 73(+) \mathrm{T}$ cells are associated with lower T-cell activation and $\mathrm{C}$ reactive protein levels and are depleted in HIV1 infection regardless of viral suppression. AIDS (2013) 27:1545-55. doi: 10.1097/QAD.0b013e328360c7f3

97. Ambada GN, Ntsama CE, Nji NN, Ngu LN, Sake CN, Lissom $A$, et al. Phenotypic characterization of regulatory $\mathrm{T}$ cells from antiretroviral-naive HIV-1-infected people. Immunology (2017) 151:405-16. doi: $10.1111 /$ imm. 12738

98. Schulze Zur Wiesch J, Thomssen A, Hartjen P, Toth I, Lehmann C, Meyer-Olson D, et al. Comprehensive analysis of frequency and phenotype of $\mathrm{T}$ regulatory cells in HIV infection: CD39 expression of FoxP3 $+\mathrm{T}$ regulatory cells correlates with progressive disease. J Virol. (2011) 85:128797. doi: 10.1128/JVI.01758-10

99. Riedel DJ, Sajadi MM, Armstrong CL, Cummings JS, Cairo C, Redfield RR, et al. Natural viral suppressors of HIV-1 have a unique capacity to maintain gammadelta T cells. AIDS (2009) 23:1955-64. doi: 10.1097/QAD.0b013e32832ff1ff

100. Sivro A, Schuetz A, Sheward D, Joag V, Yegorov S, Liebenberg LJ, et al. Integrin alpha4beta7 expression on peripheral blood CD4(+) T cells predicts HIV acquisition and disease progression outcomes. Sci Transl Med. (2018) 10:eaam6354. doi: 10.1126/scitranslmed.aam6354

101. Hersperger AR, Martin JN, Shin LY, Sheth PM, Kovacs CM, Cosma GL, et al. Increased HIV-specific CD8+ T-cell cytotoxic potential in HIV elite controllers is associated with T-bet expression. Blood (2011) 117:3799-808. doi: 10.1182/blood-2010-12-322727

102. Migueles SA, Osborne CM, Royce C, Compton AA, Joshi RP, Weeks KA, et al. Lytic granule loading of CD8 $+\mathrm{T}$ cells is required for HIV-infected cell elimination associated with immune control. Immunity (2008) 29:1009-21. doi: 10.1016/j.immuni.2008.10.010

103. Saez-Cirion A, Lacabaratz C, Lambotte O, Versmisse P, Urrutia A, Boufassa F, et al. HIV controllers exhibit potent CD8 T cell capacity to suppress HIV infection ex vivo and peculiar cytotoxic T lymphocyte activation phenotype. Proc Natl Acad Sci USA. (2007) 104:6776-81. doi: 10.1073/pnas.0611244104

104. Hersperger AR, Pereyra F, Nason M, Demers K, Sheth P, Shin LY, et al. Perforin expression directly ex vivo by HIV-specific CD8 T-cells is a correlate of HIV elite control. PLoS Pathog. (2010) 6:e1000917. doi: 10.1371/journal.ppat.1000917

105. Migueles SA, Laborico AC, Shupert WL, Sabbaghian MS, Rabin R, Hallahan $\mathrm{CW}$, et al. HIV-specific CD8+ T cell proliferation is coupled to perforin expression and is maintained in nonprogressors. Nat Immunol. (2002) 3:1061-8. doi: 10.1038/ni845

106. Shasha D, Karel D, Angiuli O, Greenblatt A, Ghebremichael M, Yu X, et al. Elite controller CD8 + T cells exhibit comparable viral inhibition capacity, but better sustained effector properties compared to chronic progressors. $J$ Leukoc Biol. (2016) 100:1425-33. doi: 10.1189/jlb.4A0915-422R

107. Juarez-Molina CI, Payne R, Soto-Nava M, Avila-Rios S, Valenzuela-Ponce $\mathrm{H}$, Adland E, et al. Impact of HLA selection pressure on HIV fitness at a population level in Mexico and Barbados. J Virol. (2014) 88:10392-8. doi: 10.1128/JVI.01162-14

108. Berger CT, Frahm N, Price DA, Mothe B, Ghebremichael M, Hartman KL, et al. High-functional-avidity cytotoxic T lymphocyte responses to HLA-B-restricted Gag-derived epitopes associated with 
relative HIV control. J Virol. (2011) 85:9334-45. doi: 10.1128/JVI.00 460-11

109. Rittiner JE, Korboukh I, Hull-Ryde EA, Jin J, Janzen WP, Frye SV, et al. AMP is an adenosine A1 receptor agonist. J Biol Chem. (2012) 287:5301-9. doi: 10.1074/jbc.M111.291666

110. Regateiro FS, Cobbold SP, Waldmann H. CD73 and adenosine generation in the creation of regulatory microenvironments. Clin Exp Immunol. (2013) 171:1-7. doi: 10.1111/j.1365-2249.2012.04623.x

111. Toth I, Le AQ, Hartjen P, Thomssen A, Matzat V, Lehmann C, et al. Decreased frequency of CD73+CD8 $+\mathrm{T}$ cells of HIV-infected patients correlates with immune activation and $\mathrm{T}$ cell exhaustion. J Leukoc Biol. (2013) 94:551-61. doi: 10.1189/jlb.0113018

112. Thompson LF. Editorial: CD73 deficiency and immune dysregulation in HIV infection: cause or effect? J Leukoc Biol. (2013) 94:545-7. doi: $10.1189 / \mathrm{jlb} .0513245$

113. Feger U, Tolosa E, Huang YH, Waschbisch A, Biedermann T, Melms A, et al. HLA-G expression defines a novel regulatory T-cell subset present in human peripheral blood and sites of inflammation. Blood (2007) 110:568-77. doi: 10.1182/blood-2006-11-057125

114. Vingert B, Benati D, Lambotte O, de Truchis P, Slama L, Jeannin P, et al. HIV controllers maintain a population of highly efficient Th1 effector cells in contrast to patients treated in the long term. J Virol. (2012) 86:10661-74. doi: 10.1128/JVI.00056-12

115. Holtmeier W, Kabelitz D. gammadelta $\mathrm{T}$ cells link innate and adaptive immune responses. Chem Immunol Allergy (2005) 86:151-83. doi: $10.1159 / 000086659$

116. Bowers E, Scamurra RW, Asrani A, Beniguel L, MaWhinney S, Keays KM, et al. Decreased mutation frequencies among immunoglobulin $\mathrm{G}$ variable region genes during viremic HIV-1 infection. PLoS ONE (2014) 9:e81913. doi: 10.1371/journal.pone.0081913

117. Lane HC, Masur H, Edgar LC, Whalen G, Rook AH, Fauci AS. Abnormalities of B-cell activation and immunoregulation in patients with the acquired immunodeficiency syndrome. N Engl J Med. (1983) 309:453-8. doi: 10.1056/NEJM198308253090803

118. Aggarwal H, Khan L, Chaudhary O, Kumar S, Makhdoomi MA, Singh R, et al. Alterations in B cell compartment correlate with poor neutralization response and disease progression in HIV-1 infected children. Front Immunol. (2017) 8:1697. doi: 10.3389/fimmu.2017.01697

119. Lai JI, Licht AF, Dugast AS, Suscovich T, Choi I, Bailey-Kellogg C, et al. Divergent antibody subclass and specificity profiles but not protective HLA$B$ alleles are associated with variable antibody effector function among HIV-1 controllers. J Virol. (2014) 88:2799-809. doi: 10.1128/JVI.03130-13

120. Chung AW, Mabuka JM, Ndlovu B, Licht A, Robinson H, Ramlakhan Y, et al. Viral control in chronic HIV-1 subtype C infection is associated with enrichment of p24 IgG1 with Fc effector activity. AIDS (2018) 32:1207-17. doi: 10.1097/QAD.0000000000001812

121. Ahmad A, Mehraj V, Jenabian MA, Routy JP, Tremblay C. Anti-Gag antibodies gag HIV infection and slow disease progression. AIDS (2018) 32:1373-5. doi: 10.1097/QAD.0000000000001852

122. Gonzalez N, McKee K, Lynch RM, Georgiev IS, Jimenez L, Grau E, et al. Characterization of broadly neutralizing antibody responses to HIV-1 in a cohort of long term non-progressors. PLoS ONE (2018) 13:e0193773. doi: 10.1371/journal.pone.0193773

123. Sadanand S, Das J, Chung AW, Schoen MK, Lane S, Suscovich TJ, et al. Temporal variation in HIV-specific IgG subclass Abs during acute infection differentiates spontaneous controllers from chronic progressors. AIDS (2017) 32:443-50. doi: 10.1097/QAD.00000000000 01716

124. Kim ES, Ackermann C, Toth I, Dierks P, Eberhard JM, Wroblewski R, et al. Down-regulation of CD73 on B cells of patients with viremic HIV correlates with B cell activation and disease progression. J Leukoc Biol. (2017) 101:1263-71. doi: 10.1189/jlb.5A0816-346R

125. Pandey JP, Namboodiri AM, Bu S, De Dieu Tapsoba J, Sato A, Dai JY. Immunoglobulin genes and the acquisition of HIV infection in a randomized trial of recombinant adenovirus HIV vaccine. Virology (2013) 441:70-4. doi: 10.1016/j.virol.2013.03.007

126. Deepe RN, Kistner-Griffin E, Martin JN, Deeks SG, Pandey JP. Epistatic interactions between $\mathrm{Fc}(\mathrm{GM})$ and FcgammaR genes and the host control of human immunodeficiency virus replication. Hum Immunol. (2012) 73:2636. doi: 10.1016/j.humimm.2011.12.008

127. French MA, Center RJ, Wilson KM, Fleyfel I, Fernandez S, Schorcht A, et al. Isotype-switched immunoglobulin G antibodies to HIV Gag proteins may provide alternative or additional immune responses to 'protective' human leukocyte antigen-B alleles in HIV controllers. AIDS (2013) 27:519-28. doi: 10.1097/QAD.0b013e32835cb720

128. Tjiam MC, Morshidi MA, Sariputra L, Martin JN, Deeks SG, Tan DBA, et al. Association of HIV-1 gag-specific IgG antibodies with natural control of HIV-1 infection in individuals not carrying HLA-B* 57 : 01 is only observed in viremic controllers. J Acquir Immune Defic Syndr. (2017) 76:e90-2. doi: $10.1097 / Q A I .0000000000001477$

129. Tjiam MC, Taylor JP, Morshidi MA, Sariputra L, Burrows S, Martin JN, et al. Viremic HIV controllers exhibit high plasmacytoid dendritic cell-reactive opsonophagocytic IgG antibody responses against HIV-1 p24 Associated with greater antibody isotype diversification. J Immunol. (2015) 194:5320-8. doi: 10.4049/jimmunol.1402918

130. Forthal DN, Landucci G, Bream J, Jacobson LP, Phan TB, Montoya B. FcgammaRIIa genotype predicts progression of HIV infection. J Immunol (2007) 179:7916-23. doi: 10.4049/jimmunol.179.11.7916

131. Poonia B, Kijak GH, Pauza CD. High affinity allele for the gene of FCGR3A is risk factor for HIV infection and progression. PLoS ONE (2010) 5:e15562. doi: 10.1371/journal.pone.0015562

132. Conter LJ, Song E, Shlomchik MJ, Tomayko MM. CD73 expression is dynamically regulated in the germinal center and bone marrow plasma cells are diminished in its absence. PLoS ONE (2014) 9:e92009. doi: 10.1371/journal.pone.0092009

133. Saze Z, Schuler PJ, Hong CS, Cheng D, Jackson EK, Whiteside TL. Adenosine production by human $B$ cells and $B$ cell-mediated suppression of activated $\mathrm{T}$ cells. Blood (2013) 122:9-18. doi: 10.1182/blood-2013-02-482406

134. Schena F, Volpi S, Faliti CE, Penco F, Santi S, Proietti M, et al. Dependence of immunoglobulin class switch recombination in B cells on vesicular release of ATP and CD73 ectonucleotidase activity. Cell Rep. (2013) 3:1824-31. doi: 10.1016/j.celrep.2013.05.022

135. Airas L, Jalkanen S. CD73 mediates adhesion of B cells to follicular dendritic cells. Blood (1996) 88:1755-64.

136. Lefranc MP, Lefranc G. Human Gm, Km, and Am allotypes and their molecular characterization: a remarkable demonstration of polymorphism. Methods Mol Biol. (2012) 882:635-80. doi: 10.1007/978-1-61779-842-9_34

137. Pandey JP. Genetic variants of Fcgamma (GM allotypes) and the Fcmediated effector functions in HIV-1 controllers. J Virol. (2014) 88:7117. doi: 10.1128/JVI.00726-14

138. Bruhns P, Iannascoli B, England P, Mancardi DA, Fernandez N, Jorieux S, et al. Specificity and affinity of human Fcgamma receptors and their polymorphic variants for human IgG subclasses. Blood (2009) 113:3716-25. doi: 10.1182/blood-2008-09-179754

139. Weis JF, McClelland RS, Jaoko W, Mandaliya KN, Overbaugh J, Graham SM. Short communication: Fc gamma receptors IIa and IIIa genetic polymorphisms do not predict HIV-1 disease progression in Kenyan women. AIDS Res Hum Retroviruses (2015) 31:288-92. doi: 10.1089/aid.2014.0209

140. Emu B, Sinclair E, Hatano H, Ferre A, Shacklett B, Martin JN, et al. HLA class I-restricted T-cell responses may contribute to the control of human immunodeficiency virus infection, but such responses are not always necessary for long-term virus control. J Virol. (2008) 82:5398-407. doi: 10.1128/JVI.02176-07

141. Boulet S, Kleyman M, Kim JY, Kamya P, Sharafi S, Simic N, et al. A combined genotype of KIR3DL1 high expressing alleles and HLA-B*57 is associated with a reduced risk of HIV infection. AIDS (2008) 22:1487-91. doi: 10.1097/QAD.0b013e3282ffde7e

142. Johansson SE, Hejdeman B, Hinkula J, Johansson MH, Romagne F, Wahren $B$, et al. NK cell activation by KIR-binding antibody 1-7F9 and response to HIV-infected autologous cells in viremic and controller HIV-infected patients. Clin Immunol. (2010) 134:158-68. doi: 10.1016/j.clim.2009.10.001

143. Martin MP, Qi Y, Gao X, Yamada E, Martin JN, Pereyra F, et al. Innate partnership of HLA-B and KIR3DL1 subtypes against HIV-1. Nat Genet. (2007) 39:733-40. doi: 10.1038/ng2035

144. Tomescu C, Duh FM, Hoh R, Viviani A, Harvill K, Martin MP, et al. Impact of protective killer inhibitory receptor/human leukocyte antigen genotypes 
on natural killer cell and T-cell function in HIV-1-infected controllers. AIDS (2012) 26:1869-78. doi: 10.1097/QAD.0b013e32835861b0

145. Martin MP, Gao X, Lee JH, Nelson GW, Detels R, Goedert JJ, et al. Epistatic interaction between KIR3DS1 and HLA-B delays the progression to AIDS. Nat Genet. (2002) 31:429-34. doi: 10.1038/ng934

146. Long BR, Ndhlovu LC, Oksenberg JR, Lanier LL, Hecht FM, Nixon DF, et al. Conferral of enhanced natural killer cell function by KIR3DS1 in early human immunodeficiency virus type 1 infection. J Virol. (2008) 82:4785-92. doi: 10.1128/JVI.02449-07

147. Mori M, Wichukchinda N, Miyahara R, Rojanawiwat A, Pathipvanich P, Miura T, et al. Impact of HLA Allele-KIR Pairs on Disease Outcome in HIVInfected Thai Population. J Acquir Immune Defic Syndr. (2018) 78:356-61. doi: 10.1097/QAI.0000000000001676

148. Eller MA, Eller LA, Ouma BJ, Thelian D, Gonzalez VD, Guwatudde D, et al. Elevated natural killer cell activity despite altered functional and phenotypic profile in Ugandans with HIV-1 clade A or clade D infection. J Acquir Immune Defic Syndr. (2009) 51:380-9. doi: 10.1097/QAI.0b013e3181aa256e

149. Marras F, Nicco E, Bozzano F, Di Biagio A, Dentone C, Pontali E, et al. Natural killer cells in HIV controller patients express an activated effector phenotype and do not up-regulate NKp44 on IL-2 stimulation. Proc Natl Acad Sci USA. (2013) 110:11970-5. doi: 10.1073/pnas.1302090110

150. Kottilil S, Chun TW, Moir S, Liu S, McLaughlin M, Hallahan CW, et al. Innate immunity in human immunodeficiency virus infection: effect of viremia on natural killer cell function. J Infect Dis. (2003) 187:1038-45. doi: $10.1086 / 368222$

151. Fogli M, Mavilio D, Brunetta E, Varchetta S, Ata K, Roby G, et al. Lysis of endogenously infected $\mathrm{CD} 4+\mathrm{T}$ cell blasts by rIL-2 activated autologous natural killer cells from HIV-infected viremic individuals. PLoS Pathog. (2008) 4:e1000101. doi: 10.1371/journal.ppat.10 00101

152. Tomescu C, Chehimi J, Maino VC, Montaner LJ. NK cell lysis of HIV-1infected autologous CD4 primary T cells: requirement for IFN-mediated NK activation by plasmacytoid dendritic cells. J Immunol. (2007) 179:2097-104. doi: 10.4049/jimmunol.179.4.2097

153. Scott-Algara D, Truong LX, Versmisse P, David A, Luong TT, Nguyen NV, et al. Cutting edge: increased NK cell activity in HIV-1-exposed but uninfected Vietnamese intravascular drug users. J Immunol. (2003) 171:5663-7. doi: 10.4049/jimmunol.171.11.5663

154. Yawata M, Yawata N, Draghi M, Little AM, Partheniou F, Parham P. Roles for HLA and KIR polymorphisms in natural killer cell repertoire selection and modulation of effector function. J Exp Med. (2006) 203:633-45. doi: 10.1084/jem.20051884

155. Carrington M, Martin MP, van Bergen J. KIR-HLA intercourse in HIV disease. Trends Microbiol. (2008) 16:620-7. doi: 10.1016/j.tim.2008. 09.002

156. O’Connor GM, Holmes A, Mulcahy F, Gardiner CM. Natural killer cells from long-term non-progressor HIV patients are characterized by altered phenotype and function. Clin Immunol. (2007) 124:277-83. doi: 10.1016/j.clim.2007.05.016

157. Elliott JM, Yokoyama WM. Unifying concepts of MHC-dependent natural killer cell education. Trends Immunol. (2011) 32:364-72. doi: 10.1016/j.it.2011.06.001

158. Alter G, Martin MP, Teigen N, Carr WH, Suscovich TJ, Schneidewind A, et al. Differential natural killer cell-mediated inhibition of HIV-1 replication based on distinct KIR/HLA subtypes. J Exp Med. (2007) 204:3027-36. doi: 10.1084/jem.20070695

159. Alsahafi N, Richard J, Prevost J, Coutu M, Brassard N, Parsons MS, et al. Impaired downregulation of NKG2D ligands by Nef proteins from elite controllers sensitizes HIV-1-infected cells to antibody-dependent cellular cytotoxicity. J Virol. (2017) 91:e00109-17. doi: 10.1128/JVI.00 109-17

Conflict of Interest Statement: The authors declare that the research was conducted in the absence of any commercial or financial relationships that could be construed as a potential conflict of interest.

Copyright (c) $2018 \mathrm{Li}$, Liu and Gorny. This is an open-access article distributed under the terms of the Creative Commons Attribution License (CC BY). The use, distribution or reproduction in other forums is permitted, provided the original author(s) and the copyright owner(s) are credited and that the original publication in this journal is cited, in accordance with accepted academic practice. No use, distribution or reproduction is permitted which does not comply with these terms. 